\title{
Diffusion-limited REE uptake by eclogite garnets and its consequences for Lu-Hf and Sm-Nd geochronology
}

\author{
Susanne Skora $\cdot$ Lukas P. Baumgartner · \\ Nancy J. Mahlen · Clark M. Johnson · \\ Sébastien Pilet · Eric Hellebrand
}

Received: 20 March 2006/ Accepted: 26 July 2006/Published online: 30 August 2006

(C) Springer-Verlag 2006

\begin{abstract}
Garnets from the Zermatt-Saas Fee eclogites contain narrow central peaks for $\mathrm{Lu}+\mathrm{Yb}+\mathrm{Tm} \pm \mathrm{Er}$ and at least one additional small peak towards the rim. The REE $\mathrm{Sm}+\mathrm{Eu}+\mathrm{Gd}+\mathrm{Tb} \pm \mathrm{Dy}$ are depleted in the cores but show one prominent peak close to the rim. These patterns cannot be modeled using Rayleigh fractionation accompanied by mineral breakdown reactions. Instead, the patterns are well explained using a transient matrix diffusion model where REE uptake is limited by diffusion in the matrix surrounding the porphyroblast. Observed profiles are well matched if a roughly linear radius growth rate is used. The secondary peaks in the garnet profiles are interpreted to reflect thermally activated diffusion due to temperature increase during prograde metamorphism. The model predicts
\end{abstract}

Communicated by J. Hoefs.

S. Skora $(\bowtie) \cdot$ L. P. Baumgartner $\cdot$ S. Pilet

Institute of Mineralogy and Geochemistry,

University of Lausanne, Anthropole,

1015 Lausanne, Switzerland

e-mail: Susanne.Skora@unil.ch

N. J. Mahlen · C. M. Johnson

Department of Geology and Geophysics,

University of Wisconsin-Madison, 1215 W. Dayton Street,

Madison, WI 53706, USA

E. Hellebrand

Max-Planck Institute for Chemistry,

Postfach 3060, 55020 Mainz, Germany

Present Address:

S. Pilet

Division of Geological and Planetary Sciences,

California Institute of Technology,

Pasadena, CA 91125, USA anomalously low ${ }^{176} \mathrm{Lu} /{ }^{177} \mathrm{Hf}$ and ${ }^{147} \mathrm{Sm} /{ }^{144} \mathrm{Nd}$ ratios in garnets where growth rates are fast compared to diffusion of the REE, and these results have important implications for $\mathrm{Lu}-\mathrm{Hf}$ and $\mathrm{Sm}-\mathrm{Nd}$ geochronology using garnet.

\section{Introduction}

Garnets are used for estimating temperatures and pressures of peak metamorphism in a wide variety of lithologies. P-T paths can readily be calculated using garnets (e.g., Spear and Selverstone 1983) and time estimates for crystallization ages can be obtained using ${ }^{147} \mathrm{Sm}-{ }^{143} \mathrm{Nd}$ and ${ }^{176} \mathrm{Lu}-{ }^{176} \mathrm{Hf}$ geochronology (e.g., Vance and O'Nions 1990; Duchêne et al. 1997). In principle, garnet geochronology places better constraints on the age(s) of specific P-T conditions for metamorphic rocks as compared to ages determined on accessory minerals such as those determined by $\mathrm{U}-\mathrm{Pb}$ zircon geochronology because accessory mineral formation is difficult to tie to specific metamorphic conditions (e.g., Whitehouse and Platt 2003).

It is commonly assumed that garnet formed in equilibrium with the matrix during porphyroblast growth. Two rate-limiting end-member processes for porphyroblast growth are typically discussed in the literature. These are interface- and diffusion-controlled growth (e.g., Kretz 1969, 1973, 1974, 1993; Fischer 1978; Carlson 1989, 1991; Kerrick et al. 1991; Carlson and Denison 1992; Carlson et al. 1995; Denison et al. 1997; Denison and Carlson 1997; Daniel and Spear 1998, 1999; Spear and Daniel 1998, 2001; Hirsch et al. 2000; Meth and Carlson 2005). Diffusion-limited 
growth implies that delivery of elements by diffusion to the growth site is relatively slow compared to the growth rate. Therefore depletion or enrichment halos develop around growing porphyroblasts, which leads to increased local element flux. This process can produce significant disequilibrium between the matrix and the growing porphyroblast. Interface-controlled growth occurs when attachment of a new garnet layer is relatively slow compared to diffusion. This will therefore produce porphyroblasts that are surrounded by a nearly homogeneous matrix, although this matrix might be far out of equilibrium (Lasaga 1986, 1998).

The three-dimensional spatial distribution, crystal size distribution, and chemical zoning patterns in porphyroblasts contain crucial information on the overall rate-limiting mechanism of crystal growth. Trace elements are particularly useful for investigating garnet growth mechanisms because they occur in minor concentrations and are not essential structural components in garnets. Their concentrations, therefore, most likely cannot influence the rate-limiting mechanism, but rather act as tracers of growth. In this contribution we investigate the rate-limiting mechanisms for garnet growth in the relatively low-temperature eclogites of the Zermatt-Saas Fee ophiolite of the western Alps. The results provide an explanation for the range in $\mathrm{REE}$ and $\mathrm{Zr}$ and $\mathrm{Hf}$ zoning observed in garnets, which in turn exerts a strong control on ${ }^{147} \mathrm{Sm}^{-143} \mathrm{Nd}$ and ${ }^{176} \mathrm{Lu}-{ }^{176} \mathrm{Hf}$ geochronology (Lapen et al. 2003).

\section{Geological setting}

The Zermatt-Saas Fee ophiolite (ZSFO) in the European Alps (Fig. 1) has attracted much attention due to the presence of ultra-high pressure rocks at the coesite locality of Lago di Cignana (Valtournenche, Italy) (Reinecke 1991, 1998; van der Klauw 1997), and the well-preserved eclogite-facies pillow structures at the Pfulwe pass area (Zermatt, Switzerland) (Bearth 1959, 1967, 1973; Oberhänsli 1980, 1982; Barnicoat and Fry 1986; Barnicoat 1988). The ZSFO is the metamorphic relict of the Liguro-Piemont oceanic crust that comprised part of the Tethys Ocean. It developed between the Briançonnais promontory and the Apulian/African continental margin (e.g., Dewey et al. 1989; Stampfli and Marchant 1997). A Jurassic protolith age $(\sim 164 \mathrm{Ma})$ has been constrained by $\mathrm{U} / \mathrm{Pb}$ ages of magmatic zircons from metagabbros in the ZSFO (Rubatto et al. 1998). A range of ages have been obtained for HP and UHP metamorphism of the ZSFO, from around 55 to $38 \mathrm{Ma}$, reflecting possible variations in peak conditions across the unit or a protracted

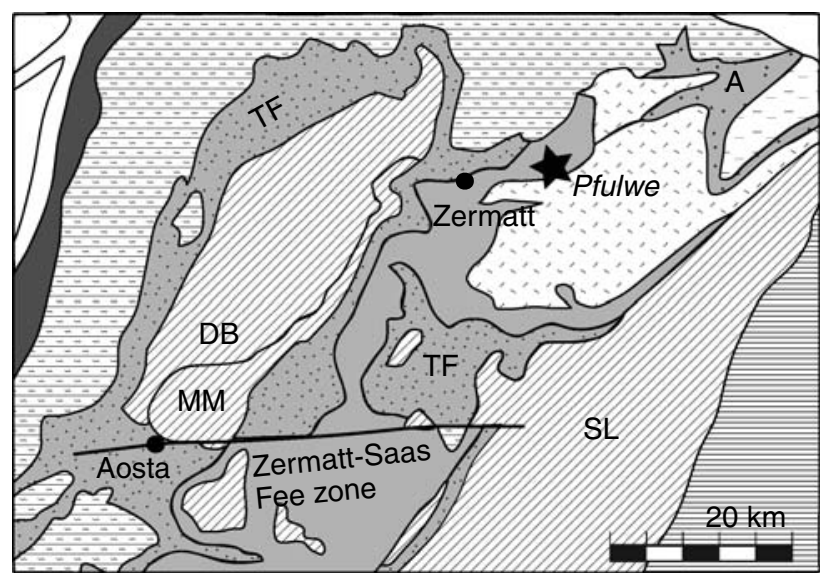

Valais zone

Grand St Bernard nappe

Monte Rosa nappe

Moncucco zone

TF-Tsaté+Mt Fort nappe

A-Antrona zone

Zermatt-Saas Fee zone

DB-Dent-Blanche, MM-Mt Mary

ZIS SL-Sesia-Lanzo zone

Southern Alps

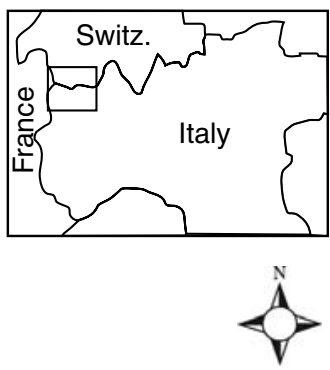

Fig. 1 Geological map of the study area in the west-central Alps (after Dal Piaz et al. 2001). The Zermatt-Saas Fee zone, an ophiolite sequence of the Tethyan Ocean, separates the DentBlanche and Sesia-Lanzo nappes from the Monte Rosa and Grand St. Bernard nappe. The samples are from the Pfulwe area, east of Zermatt, Switzerland

metamorphic history (Bowtell et al. 1994; Rubatto et al. 1998; Amato et al. 1999; Mayer et al. 1999; Dal Piaz et al. 2001; Lapen et al. 2003; Mahlen et al. 2005). Subsequent greenschist alteration occurred during exhumation, which may be spatially linked to faults, albite veins, and tectonic contacts (e.g., Bowtell et al. 1994; Cartwright and Barnicoat 2002). The ZSFO together with the associated overlying Tsaté nappe (upper Combin zone, Satori 1987) lies structurally between the continental basement rocks of the overlying Dent Blanche and Grand St. Bernard nappes and the underlying Monte Rosa nappe (e.g., Bearth 1967). The ZSFO contains all components that are typical of ophiolitic sequences including ultramafic rocks, gabbros, basalts, and radiolarites that have been partially dismembered. Serpentinite bodies often separate metagabbro, metabasalts and metasediments (Bearth 1967, 1973; Oberhänsli 1980, 1982; Barnicoat and Fry 1986).

Formation, subduction, and obduction processes of the ZSFO and related zones are discussed in more detail in several papers, including those of Oberhänsli (1994), Froitzheim et al. (1996), Escher and Beaumont (1997), and Stampfli et al. (1998). 


\section{Petrography of samples studied}

The samples for this study come from the Pfulwe pass area $(\sim 7 \mathrm{~km}$ E of Zermatt, Switzerland). They contain omphacite + garnet + paragonite + rutile + apatite + quartz + glaucophane + epidote/clinozoisite \pm carbonate \pm pyrite in variable amounts.

Omphacites are the most abundant matrix mineral in the eclogitic samples and were originally grown in $\mathrm{mm}$-sized radial bundles. Today, they mostly appear as abundant small subgrains $(-0.1-0.3 \mathrm{~mm})$ with undulatory extinctions, often preserving the original radial arrangement. All white micas in our samples are paragonites, although muscovites and phengites have been described for the eclogites of the Pfulwe pass area (Bearth 1959, 1967, 1973; Barnicoat and Fry 1986). Glaucophane modes and sizes in the matrix can vary from $\sim 0.2 \mathrm{~mm}$ up to several $\mathrm{mm}$-sized grains within a thin section. Epidote/clinozoisite $(\sim 0.1-1 \mathrm{~mm})$ is often zoned and has Fe-rich cores; these minerals are always present in the matrix and occur as inclusions in various minerals. Rutiles are small $(\sim 0.1-0.2 \mathrm{~mm})$ but abundant in all samples and commonly occur as inclusions in all minerals. Titanite is found very rarely in the matrix as rims around rutile in our samples. Carbonates are typically interstitial to matrix minerals. Apatite and quartz occur in minor amounts in the matrix and as inclusions in garnet.

Garnet grains are sub- to anhedral and may be up to $1 \mathrm{~cm}$ in size. Strong prograde zoning is present for $\mathrm{Mn}$, $\mathrm{Fe}$, and $\mathrm{Mg}$, whereas $\mathrm{Ca}$ is only slightly zoned. The spessartine and grossular contents of the largest garnets are highest in the cores whereas almandine and pyrope contents are highest towards the rims (Fig. 2). The calculated andradite content is very small, most likely within the error of the analysis. The core-rim $\mathrm{Mn}, \mathrm{Fe}, \mathrm{Mg}$, and $\mathrm{Ca}$ profiles of all samples are not monotonic and exhibit shoulders or even additional minima and/or maxima towards the rim (Fig. 2). All garnets typically contain abundant inclusions. Their cores have many small inclusions whereas their rims have fewer but larger inclusions. In general, rutile, glaucophane, quartz, and apatite inclusions occur throughout the garnets, whereas epidote/clinozoisite and ilmenite inclusions are more abundant in the garnet cores. Omphacite is the most common inclusion in all garnets and is typically more abundant (compared to other minerals) towards the rims. Garnet growth was therefore likely initiated during late blueschist/ early eclogite facies metamorphism, where glaucophane and epidote/clinozoisite were present and omphacite growth had already started. Approximately bell-shaped crystal size distributions (Skora et al. in preperation) suggest continuous nucleation and growth throughout the garnet growth history (e.g., Cashman and Ferry 1988).

Peak metamorphic conditions in eclogites of the Pfulwe and the nearby Allalin peak area were estimated to be $\sim 15-20 \mathrm{kbar}$ and $550-600^{\circ} \mathrm{C}$ (Chinner and Dixon 1973; Oberhänsli 1980, 1982; Meyer 1983; Barnicoat and Fry 1986; Ganguin 1988), whereas Bucher et al. (2005) infer higher pressures of $\sim 25-30$ kbar.

\section{Analytical methods}

Central cuts of garnets were prepared for microprobe analysis using the SkyScan-1072 X-ray tomography facility $(\mu \mathrm{CT})$ at the University of Lausanne. Rock cores of $1.8 \mathrm{~cm}$ diameter and $\sim 3 \mathrm{~cm}$ length were marked with small saw cuts $(\sim 150 \mu \mathrm{m}$ thick $)$ and subsequently scanned with the $\mu \mathrm{CT}$ operating at $70 \mathrm{kV} / 140 \mathrm{nA}$ or at $80 \mathrm{kV} / 120 \mathrm{nA}$ for 4-10 h. Garnets were chosen based on their sizes and shapes. Rock cores were cut slightly off center of the garnets and carefully ground down to $100 \mu \mathrm{m}$ above or below the
Fig. 2 Cations calculated per 12 oxygen, measured along the profile marked in the Mn compositional map to the right. All garnet profiles have Mn shoulders half way from the center to the rim, but no indication of garnet resorption can be seen here
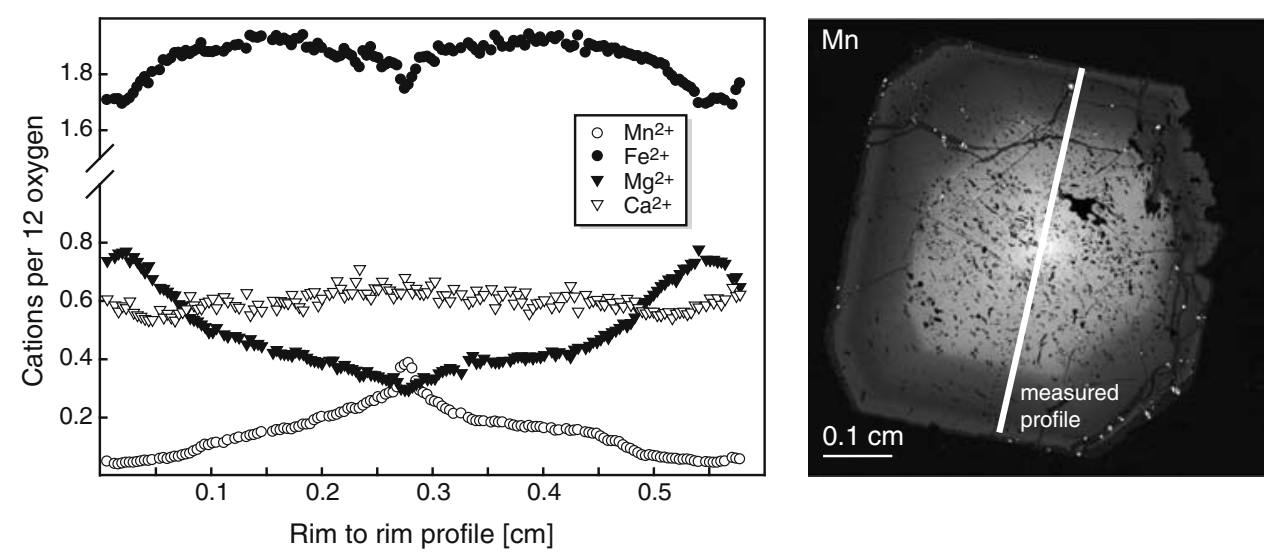
center. A $100 \mu \mathrm{m}$ thick thin section was prepared and ground down to obtain microprobe sections that yielded garnet cross sections corresponding to the central tomographic images. Although great care was taken to ensure the location of sections, an uncertainty of up to $100 \mu \mathrm{m}$ may exist for the largest garnets.

Wavelength-dispersive quantitative electron microprobe analyses were obtained at the University of Lausanne using a Cameca SX-50 (5 spectrometers). Garnet X-ray maps for $\mathrm{Ca}, \mathrm{Mg}, \mathrm{Fe}$ and $\mathrm{Mn}$ were obtained prior to quantitative analysis to identify the chemical center (Fig. 2). Garnet profiles were measured with a focused beam with an acceleration voltage of 15 or $20 \mathrm{kV}$ and a current of $20 \mathrm{nA}$.

Laser ablation inductively coupled with plasma mass spectrometry (LA-ICP-MS) analyses were carried out at the University of Lausanne. The facility uses an excimer laser $(193 \mathrm{~nm})$ coupled to a Perkin-Elmer ELAN 6100 DRC ICP-MS (see also Günter et al. 1997) (laser settings: $7 \mathrm{~Hz}, 28 \mathrm{kV}$, energy $\sim 170 \mathrm{~mJ}$, fluency $\sim 13 \mathrm{~J} / \mathrm{cm}^{2}$; acquisition time: gas blank $\sim 40 \mathrm{~s}$, data $\sim 60 \mathrm{~s}$ ). A spot size of $30 \mu \mathrm{m}$ was chosen for garnet profiles as a compromise between ICP and MS sensitivity and spatial resolution after testing different spot sizes on a polished sample of Gore Mountain garnet. "Whole rock" trace and rare earth element measurements were carried out by integrating three spot analyses $(80 \mu \mathrm{m})$ of fusion discs. Data were reduced using the convert and lamtrace programs (Longerich et al. 1996). NIST612 glass was used as external standard and $\mathrm{Ca}$ electron microprobe measurements served as an internal standard. BCR-2 glass or NIST610 was monitored during all analytical sessions and treated as unknowns during data reduction. The error is estimated to lie between $5-10 \%$ on a relative basis. Surface inclusions were avoided using a video camera. Subsurface inclusions were identified using major element compositions obtained with the laser, including $\mathrm{Ca}$ (apatite), $\mathrm{Na}$ (omphacite, amphibole, and paragonite), $\mathrm{Ti}$ (rutile, ilmenite, and titanite), $\mathrm{Zr}$ (zircons), and $\mathrm{Sr}$ ( $\mathrm{K}$ proxy). Analyses containing significant amounts of these elements, or where significant variations occurred were excluded from the averaging procedure for each point, using counts per second versus time diagram.

A subset of samples was analyzed by secondary ion mass spectrometry (SIMS) at the Max Planck Institute of Chemistry (Mainz). An upgraded Cameca IMS-3f was used and SIMS measurements were obtained adjacent to the LA-ICP-MS spots. Negative oxygen ions were used as the primary ion beam (accelerating voltage: $12.5 \mathrm{kV}$; beam current: $20 \mathrm{nA}$; spot size $\sim 20 \mu \mathrm{m})$. The method followed the six-cycle routine described in Hellebrand et al. (2002). Light rare earth elements (LREE) were measured for $60 \mathrm{~s}$ whereas heavy rare earth elements (HREE) were measured for $15 \mathrm{~s}$ per cycle. The low-concentration GOR-132 MPI-DING reference glass (Jochum et al. 2000) was used as external standard with its REE pattern similar to garnets of the ZSFO. For one of the garnet profiles, the REE contents by SIMS and LAICP-MS agree very well. The second garnet profile, however, produced consistently higher values $(\sim 30 \%)$ by SIMS analysis. The origin of this discrepancy is likely due to the fact that this sample was mounted slightly inclined because it was a fragment. This resulted in different beam/sample/detector geometry between SIMS sample and standard. Removing contaminated cycles prior to final data reduction minimized the effect of inclusions encountered during ablation.

\section{Results}

Garnet rare earth element geochemistry

The REEs display prominent changes in the zoning pattern from $\mathrm{Sm}$ (enriched close to the rims) towards $\mathrm{Lu}$ (enriched in the cores) in all samples (Fig. 3). Here, we will focus on the profiles for the largest garnets found in a sample.

$\mathrm{Sm}, \mathrm{Eu}, \mathrm{Gd}$, and $\mathrm{Tb}$ are typically depleted in the core $(\sim 0.1-0.2 \mathrm{ppm}$ for $\mathrm{Sm}, \mathrm{Eu} ; 1-2 \mathrm{ppm}$ for $\mathrm{Gd}$, $\mathrm{Tb})$ and display at least one peak close to the rim ( 0.3-0.8 ppm for $\mathrm{Sm}, \mathrm{Eu} ; \sim 3-14 \mathrm{ppm} \mathrm{Gd}, \mathrm{Tb})$. In general, $\mathrm{Ho}$ and $\mathrm{Y}$ are enriched in the cores ( 15-35 ppm for Ho; 400-800 ppm for $\mathrm{Y}$ ) compared to their rims $(\sim 2-5 \mathrm{ppm}$ for $\mathrm{Ho} ; \sim 50-100 \mathrm{ppm}$ for $\mathrm{Y})$. For samples where Ho and $\mathrm{Y}$ contents are low in the cores, concentrations first decrease then subsequently increase before the outermost rim is depleted again (M-shape with central peak, Fig. 3). Samples that have high $\mathrm{Ho}$ and $\mathrm{Y}$ concentrations in the cores exhibit one rather broad peak and an additional maximum. Dy may be depleted in the core $(\sim 20-30 \mathrm{ppm})$ along with one peak close to the rim ( $\sim 50-60 \mathrm{ppm})$, similar to $\mathrm{Gd}$ and $\mathrm{Tb}$; in other cases, Dy may have similar zoning patterns as Ho and Y, where maximum central compositions are $\sim 30-60 \mathrm{ppm}$, decreasing to $\sim 10 \mathrm{ppm}$ rim wards, generally followed by an additional peak towards the rim.

The HREEs have sharp peaks in the garnet cores, as well as an additional maximum towards the rim. The width of the HREE peaks is approximately $1 / 5$ of the 

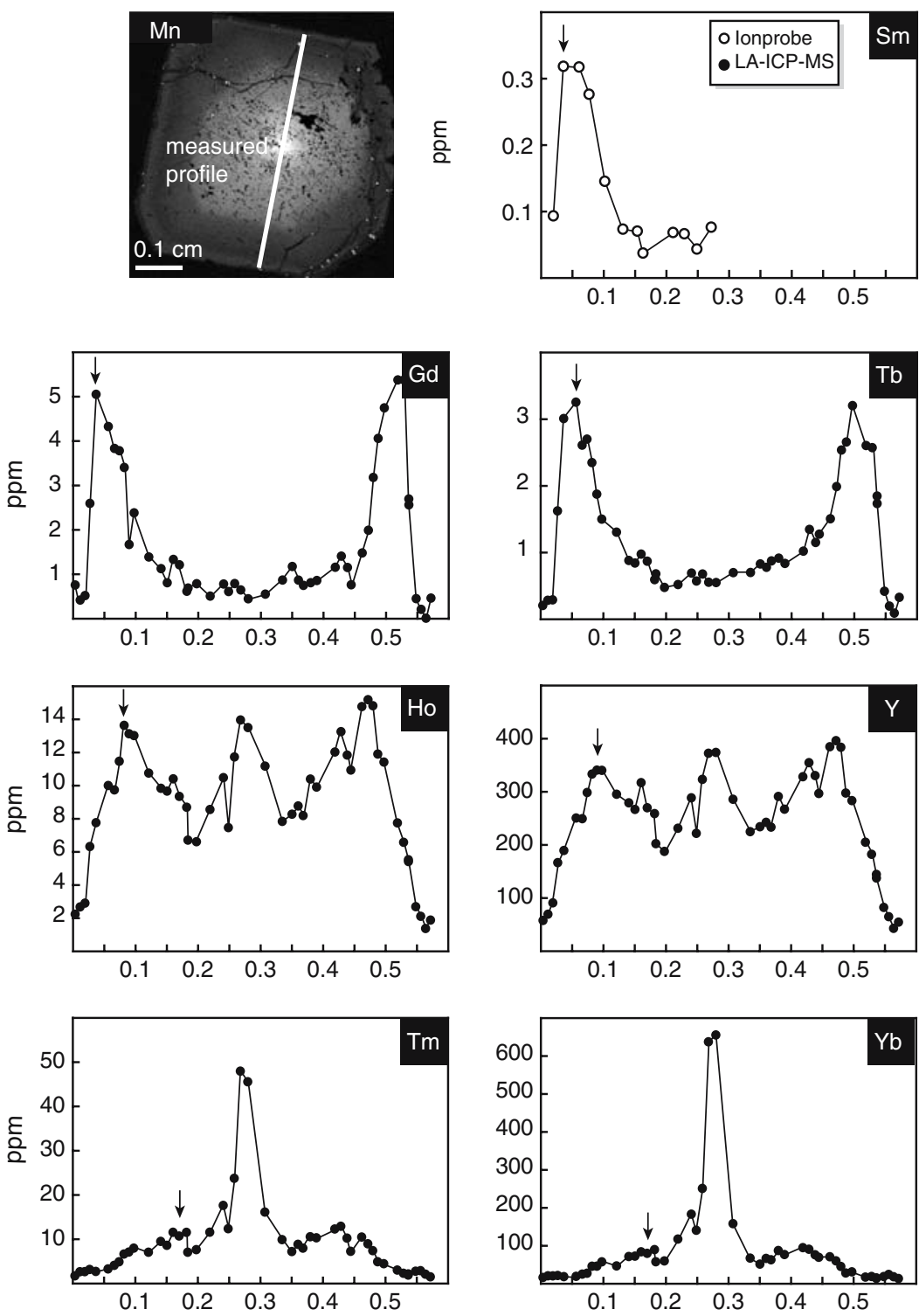
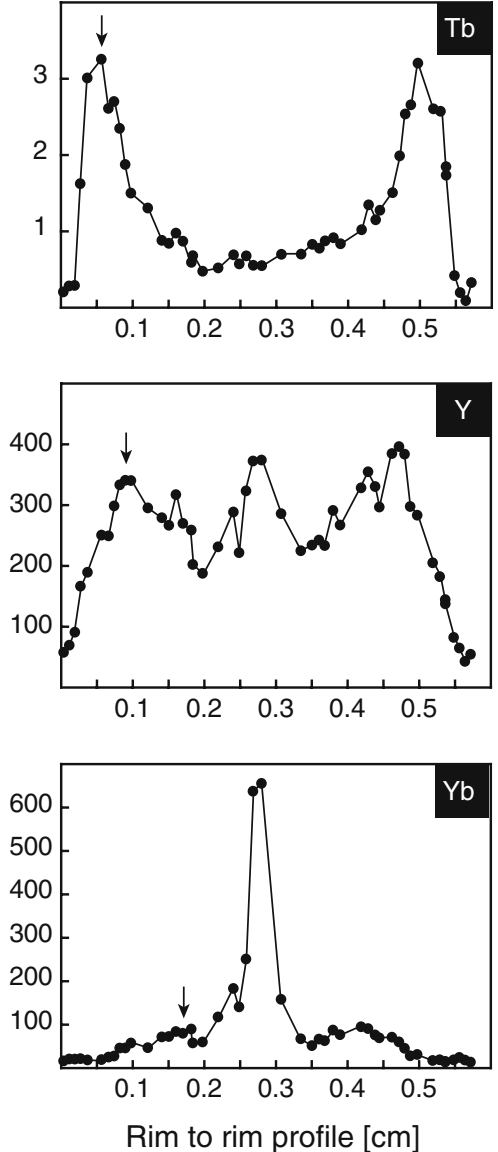
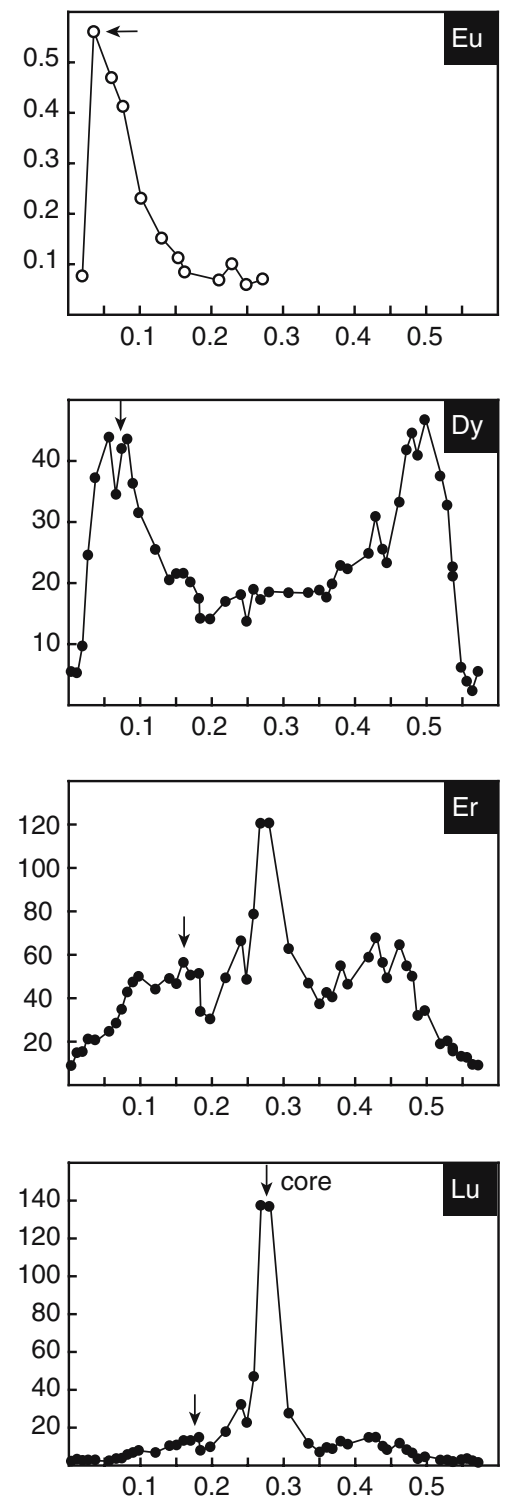

Fig. 3 REE profiles through the eclogite garnet from Figure 2. Profiles display prominent changes in the zoning pattern from LREE (depleted cores, enriched close to the rims) to HREE (enriched cores, depleted rims). A second maximum developed rim wards (indicated by arrows). It wanders towards the rim with decreasing $\mathrm{Z}$. Sm and $\mathrm{Eu}$ are measured with the ionprobe; all other elements are measured with the LA-ICP-MS radius, and is therefore very sensitive to uncertainties in the central cuts. Quantification of the core HREE peaks is further complicated by the fact that the cores generally have high inclusion densities. Measured concentrations in the core are between $\sim 60$ and $260 \mathrm{ppm}$ for $\mathrm{Er}$ and $\sim 30-90 \mathrm{ppm}$ for Tm. An additional maximum of $\sim 30-100 \mathrm{ppm}$ for Er and $\sim 10-15 \mathrm{ppm}$ for $\mathrm{Tm}$ is observed towards the rim. The rim composition is $\sim 10-20 \mathrm{ppm}$ for $\mathrm{Er}$ and $\sim 1-3 \mathrm{ppm}$ for $\mathrm{Tm}$. The concentration difference between the core and rim ward peak is more pronounced for $\mathrm{Yb}$ and $\mathrm{Lu}$. Measured core compositions are between $\sim 120$ and $940 \mathrm{ppm}$ for $\mathrm{Yb}$ and $\sim 30-200 \mathrm{ppm}$ for $\mathrm{Lu}$. The additional maximum is between $\sim 30$ and $90 \mathrm{ppm}$ for $\mathrm{Yb}$ and $\sim 5-15 \mathrm{ppm}$ for $\mathrm{Lu}$. The rim compositions decrease to $\sim 5-30 \mathrm{ppm}$ and $\sim 1-3 \mathrm{ppm}$ for $\mathrm{Yb}$ and $\mathrm{Lu}$, respectively. These relations indicate a consistent pattern of "secondary peaks" in the zonations that are shifted successively towards the rim with decreasing atomic number (Z) for REEs (Fig. 3). 


\section{Discussion}

Garnet growth mechanisms and zoning patterns

Two end-member rate-limiting mechanisms have been proposed to control the kinetics of porphyroblast growth: interface- (slow surface reaction kinetics) and diffusion-controlled (see introduction) (e.g., Kretz 1969, 1973, 1974, 1993; Fischer 1978; Carlson 1989, 1991; Kerrick et al. 1991; Carlson and Denison 1992; Carlson et al. 1995; Denison et al. 1997; Denison and Carlson 1997; Daniel and Spear 1998, 1999; Spear and Daniel 1998, 2001; Hirsch et al. 2000; Meth and Carlson 2005). These different growth-limiting mechanisms exert an influence on the distribution of porphyroblasts in the rock and are associated with different growth rate laws (diffusion-controlled: surface-constant growth rate law; interface-controlled: radius-constant growth rate law; see above). In turn, the different growth rate laws should be reflected in distinct chemical zoning in individual porphyroblasts. Hence chemical contour lines can be used as time markers if all porphyroblasts (e.g., all garnets) in a specimen precipitated the same chemical composition at any point in time.

We conclude that all garnets of the Zermatt-Saas Fee eclogites, regardless of their size, precipitated the same amount of radius for a given time step because the rim composition of large and small garnets approximately plot on top of each other if their rims are aligned (Skora et al. 2005, Skora et al. in prep.). Hence the same amount of garnet radius was precipitated on small and on large garnets at any given time. This constant radius growth rate law is in agreement with kinetics controlled by surface reaction (Kretz 1973, 1974) although temperature-accelerated, diffusion-controlled growth can also result in an approximately linear growth rate law (Carlson and Ketcham 2006). In agreement with this observation we will use a linear growth rate for the radius of the garnets. We note that surface reaction kinetics are also a thermally activated process and hence will vary throughout the garnet growth interval. We nevertheless believe that a constant growth rate is a reasonable assumption considering the present lack of quantitative data for reaction kinetics in eclogites.

In contrast to major element zoning patterns, concentrations of the heaviest REE $(\mathrm{Er}+\mathrm{Tm}+\mathrm{Yb}+\mathrm{Lu})$ are always enriched in the cores of smaller garnets relative to their concentrations at the corresponding distance from the rim of larger garnets (Skora et al. 2005) (Fig. 4). This pattern implies that concentration gradients were present in the matrix because each radial increment of smaller garnets grew contemporaneously with radial increments of larger garnets, when the rims are aligned in major element zoning. HREE concentration gradients are interpreted to be diffusion halos that surrounded garnets that nucleated earlier. The absolute concentrations of the central peaks decrease with decreasing sizes. Two possible mechanisms can be invoked to explain the systematic decrease of the central peak concentrations for smaller garnets. On one hand smaller garnets could have nucleated in an already partially depleted matrix, if diffusion halos were large enough, so that the overall matrix composition became significantly depleted. Alternatively, this pattern could reflect a decrease in $K_{D}$ with increasing temperature, or a combination of both effects.

Based on the observations discussed above, incorporation of the HREEs is interpreted to be controlled by diffusion, whereas the overall garnet growth was most likely controlled by slow surface reaction kinetics. We further assume that trace-element concentrations did not influence the overall growth rate. Trace-element zonations in garnet are a passive tracer of growth and mass-transport processes.

\section{Modeling REE uptake}

The concentrations of HREE decrease exponentially from the central peak. It occurs over too short a distance to be explained by a Rayleigh process.

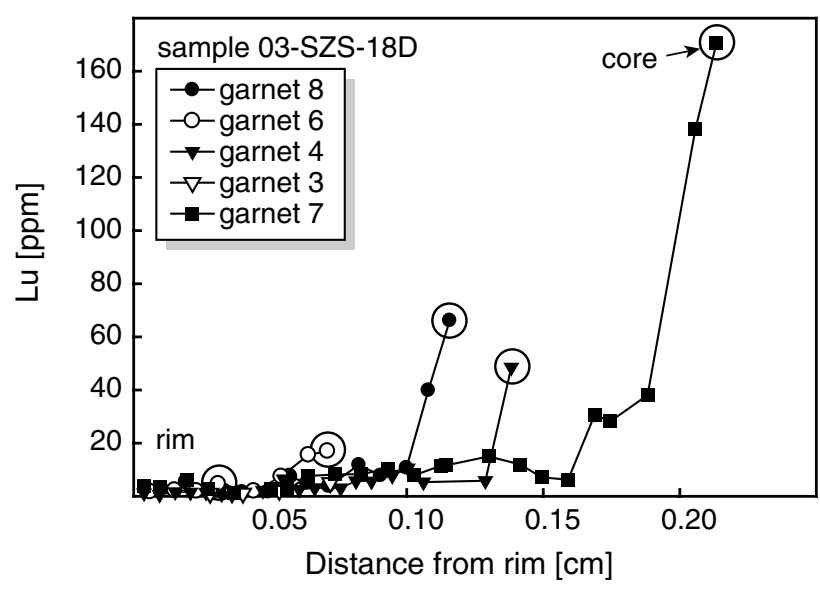

Fig. $4 \mathrm{Lu}$ concentrations plotted against distance from the rim for different sized garnets. All garnets are from the same sample, 03-SZS-18D. Major elements for all garnets indicate precipitation of the same $\Delta r$ at any point in time, because their profiles plot roughly on top of each other. In contrast, Lu concentrations in the cores of smaller garnets are always enriched relative to $\mathrm{Lu}$ contents at the same distance from the rim when compared to larger garnets. Hence, Lu concentration gradients were present in the matrix during garnet growth, most likely due to developing Lu diffusion halos around early-crystallized garnets 
Furthermore, rim values do not approach zero as expected for the Rayleigh process (Hollister 1966). As argued above, diffusion halos were likely present, where their existence is inferred from the HREE garnet zoning patterns. This is inconsistent with a Rayleigh fraction model where the matrix is homogeneously depleted (Hollister 1966).

Based on these observations, we have used a transient, bulk matrix diffusion model to match the observed core-to-rim REE zonations. Trace-element uptake is limited by the diffusion rates of the REE in the matrix surrounding the porphyroblast. The overall garnet growth was modeled with a linear growth rate for surface kinetics control and as the square root of time for diffusion-controlled growth (e.g., Weare et al. 1976; Baumgartner et al. 2005). Both growth mechanisms are certainly temperature dependant and an increased garnet growth rate at higher temperatures along a prograde PT path is expected (e.g., Carlson 1989). In fact, overall garnet growth is likely to have been a very complex function resulting from the interplay between the growth mechanisms, as well as bulk rock composition, in as much as garnet isopleths in $\mathrm{P}-\mathrm{T}$ trajectories are non uniformly distributed (e.g., Spear et al. 1991). Detailed modeling of the phase petrology of these eclogites, which are rich in $\mathrm{Fe}^{3+}$, is beyond the scope of the present publication. We emphasize that the proposed rate laws serve largely to illustrate the principle effects of diffusion-limited, trace-element incorporation.

Model: the model system consists of a sphere of fixed size in which a single garnet nucleates and grows. The matrix in the sphere is approximated by a continuum containing an average initial REE concentration, representing the fine-grained matrix of our sample. The averaged diffusion coefficient, $D$, of the REE through the matrix (grain boundary and volume diffusion) is calculated as a function of temperature following the Arrhenius equation, $D=D_{0} \exp (-Q / \mathrm{RT})$, where $D_{0}$ is the pre-exponential factor, $Q$ is the activation energy, $T$ is the temperature, and $R$ is the universal gas constant. The rim composition of the newly precipitated garnet is calculated based on the equilibrium partition coefficient $K_{D}$, which has been held constant in our modeling. The measured sharp central peaks imply relatively slow volume diffusion rates within the grown garnet, at least for the HREE, although we note that the central peak could have been initially even sharper and higher. For simplicity, volume diffusion within the grown garnet is neglected. For additional details of the model see Appendix.

\section{Specific model conditions}

The calculations reported here were performed for an eclogite from the Pfulwe area (coordinates (SUI): $630.646 / 096.146,2,940 \mathrm{~m}$ ) that contains evidence for only minor retrogression. It primarily consists of large (mm-sized) garnets $(-20 \%)$ in a matrix rich in finegrained omphacite $(\sim 60 \%)$, along with large paragonites $(\sim 10 \%)$. Minor rutile/ilmenite/ore $(\sim 1 \%)$, apatite $(\sim 3 \%)$, epidote/clinozoisite $(\sim 4 \%)$, and glaucophanes $(\sim 2 \%)$ occur dispersed within the matrix. All calculations assume an increase of temperature during garnet growth from $450^{\circ} \mathrm{C}$ to $600^{\circ} \mathrm{C}$ over a time period of 12 m.y., based on the garnet growth interval estimated from contrasting ${ }^{147} \mathrm{Sm}-{ }^{143} \mathrm{Nd}$ and ${ }^{176} \mathrm{Lu}-{ }^{176} \mathrm{Hf}$ ages by Lapen et al. (2003) for nearby eclogites from the ZSFO of the Valtournenche area. The lower temperature limit of $450^{\circ} \mathrm{C}$ is constrained by petrologic observations; garnet growth was likely initiated during upper blueschist/lower eclogite facies metamorphism, where glaucophane and epidote/clinozoisite were present and omphacite growth had just started. This lower limit is in agreement with temperature estimates from other garnet-bearing blueschist-facies rocks that are interpreted to have formed within the range of $350-480^{\circ} \mathrm{C}$ (e.g., Brown et al. 1986; Patrick and Evans 1989; Katzir et al. 2000). The upper limit of $600^{\circ} \mathrm{C}$ is based on peak temperature estimates for the Pfulwe area (Oberhänsli 1980, 1982; Barnicoat and Fry 1986; Ganguin 1988; Bucher et al. 2005). Temperature evolution was taken to increase non-linearly $\left(T \sim t^{2}\right)$ to account for the fact that heating is more rapid once convergence, and hence subduction has slowed (e.g., Roselle and Engi 2002).

The size of the system is a critical input parameter because it fixes the overall mass balance of the REE. Element availability for the first garnet equals an infinite system size, which gets steadily smaller during crystallization, when new garnets nucleate in the vicinity of pre-existing garnets. $A$ priori knowledge of the system size is difficult for most cases because it requires the knowledge of the nucleation and growth history of the nearest neighbors in 3D. We have therefore chosen a garnet, which is one of the largest in the sample (garnet \#4 from sample 03-SZS-18E, diameter of $5.4 \mathrm{~mm}$; Fig. 2). It likely nucleated early in an un-depleted matrix. The nearest neighbor was of similar size, although its actual center is just slightly outside the X-ray tomography image, and we infer that it likely nucleated simultaneously. These observations suggest that the half-distance from center to center to the nearest neighbor $(\sim 0.5 \mathrm{~cm})$ is a reasonable estimate for the system size. A slightly larger system of $0.60 \mathrm{~cm}$ 
was required to obtain the best fit for Y (Fig. 5). In the case of $\mathrm{Lu}$, which has the highest $K_{D}$ for the REEs in garnets, a minimum system size of $0.65 \mathrm{~cm}$ is needed to provide the levels of $\mathrm{Lu}$ observed in the garnet. The very good agreement between model and measurement for system size supports the modeling.

The activation energy $Q$ and the pre-exponential diffusion factor for REE matrix diffusion are the least constrained values. In our case, the REE availability and transport is likely a complex interplay of diffusion of REEs from within precursor minerals onto its grain boundaries, as well as liberation of REEs from reacting minerals, followed by grain boundary diffusion towards the growing porphyroblast. No attempt was made to separate out these effects, and we do not consider issues such as REE segregation onto grain boundaries, grain boundary diameter, and tortuosity on the bulk diffusion coefficient (e.g., Brady 1983; Baumgartner and Rumble 1988; Herzig and Mishin 1998; Dohmen and Chakraborty 2003; Hiraga et al. 2004). In any case we expect several of these factors will change significantly with changes in microstructure in the matrix during the growth of the garnet. We therefore treat diffusion coefficients as variables to be fitted to the observed profiles. The fitted diffusion parameters hence represent an apparent bulk diffusion coefficient for the individual REE including all above-mentioned parameters.

Garnet central peak concentrations of the profiles were compared to the whole rock REE concentrations to estimate the bulk $K_{D}$ for each element (approach of Hollister 1966). This simple approach assumes that the

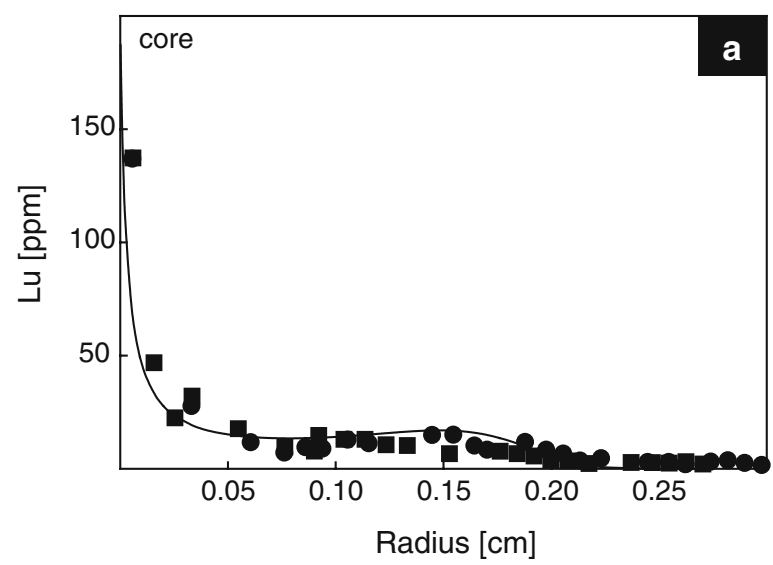

Fig. 5 Calculated fits to measured $\mathrm{Lu}$ and $\mathrm{Y}$ profiles using a transient, polythermal matrix diffusion model in which REE uptake is limited by diffusion of the species through the matrix towards the growing garnet. The diffusion coefficient is calculated following an Arrhenius equation. Garnet is assumed to grow according to $r_{\text {grt }}=\alpha$ t. Circles and squares represent both sides of the measured profiles through one garnet. The modeled results fit well the exponential inner profiles as well as the participating matrix concentration during garnet growth was equal to today's whole rock concentration. We note that calculation of $K_{D}$ for elements that have very sharp central peaks are particularly sensitive to uncertainties in the location of the central cut. The fact that the two largest HREE values in the core are approximately the same (Fig. 3) indicates that the central value is geometrically bracketed by these analyses and that the initial concentration of garnet needs to be extrapolated for HREE. A fitted partition coefficient for $\mathrm{Lu}^{\text {grt-matrix }}$ of 460 is in agreement with previous determined $K_{D}$ 's of $\mathrm{Lu}^{\text {grt-cpx }}$ in natural eclogites (e.g., Sassi et al. 2000), which range from $\sim 58$ to 500 (median: 4430 ). However, a fitted $K_{D}$ for $\mathrm{Y}^{\text {grt-matrix }}$ of 15 is lower than the $K_{D}$ 's determined for $\mathrm{Y}^{\text {grt-cpx }}$ in natural eclogites (83-200, median: 100; Sassi et al. 2000). This discrepancy could point towards a second phase that sequestered Y.

Linear growth rate law

Three trace element profiles were modeled that are representative of each type of zoning: Sm (depleted core, peak near the rim), Y ("M"-shaped zoning with central peak), and Lu (sharp peak in the center, exponential decrease towards the rim). The model readily reproduces the latter two profiles, assuming that garnet grew proportionally to time. Figure $5 \mathrm{a}$ or $\mathrm{b}$ shows the calculated visual best fit for the activation energy, pre-exponential diffusion factor, and partition coefficient to our measured values.

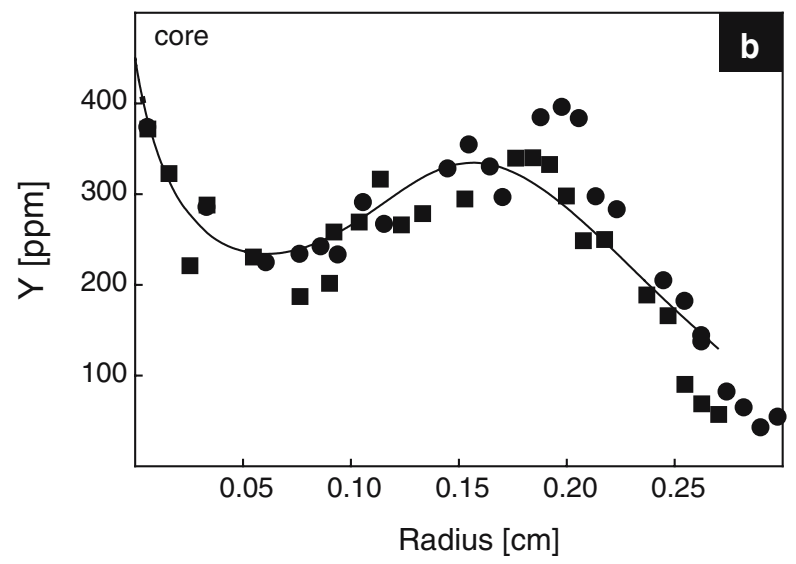

additional maximum occurring rim wards. The latter is due to diffusion halo relaxation with increasing temperatures. The temperature increases from 450 to $600^{\circ} \mathrm{C}$ with $T \sim t^{2}$ for both profiles. Input parameters are: a $K_{\mathrm{D}}=460$; system size $=$ $0.65 \mathrm{~cm} ; Q=180 \mathrm{~kJ} / \mathrm{mol} ; D_{0}=2.8 \times 10^{5} \mathrm{~cm}^{2} /$ year; b $K_{\mathrm{D}}=15$; system size $=0.60 \mathrm{~cm} ; \quad Q=300 \mathrm{~kJ} / \mathrm{mol} ; \quad D_{0}=4.0 \times 10^{13} \mathrm{~cm}^{2} /$ year; both profiles: $t=12$ m.y.; $\alpha=2.25 \times 10^{-8} \mathrm{~cm} /$ year 
The model also successfully produces the distinctive secondary peak that is observed in the data. The second maximum produced in our model reflects the fact that diffusion rates increase as temperature increases during garnet growth. Subsequent relaxation of the diffusion profile occurs surrounding the garnet during increased temperature, which causes the garnet to take more of the element at a certain point in the growth history (Fig. 6).

Similar peaks have been found in other garnet profiles (e.g., Hickmott et al. 1987; Lanzirotti 1995; Yang and Rivers 2002; Lapen et al. 2003). These secondary peaks have been previously ascribed to open-system behavior, possibly reflecting fluid infiltration, breakdown of a refractory REE-bearing mineral, a change in the garnet-forming reaction, or changes in growth kinetics. Breakdown reactions involving major phases should affect the major element profiles in the garnets, but such changes are not observed in our samples. In addition, the peak for all REEs contained in the breakdown phase(s) should lie at the same core-rim position if the phase was not zoned initially. Accessory mineral breakdown, such as the titanite-rutile transition, or breakdown of REE-rich accessory minerals such as epidote, lawsonite, or apatite, has not been observed in the samples or at the expected core-rim position in garnet for prograde metamorphism. The garnet has only rutile inclusions indicating that the titanite to rutile transformation occurred prior to garnet growth. No traces of lawsonite or its pseudomorphs

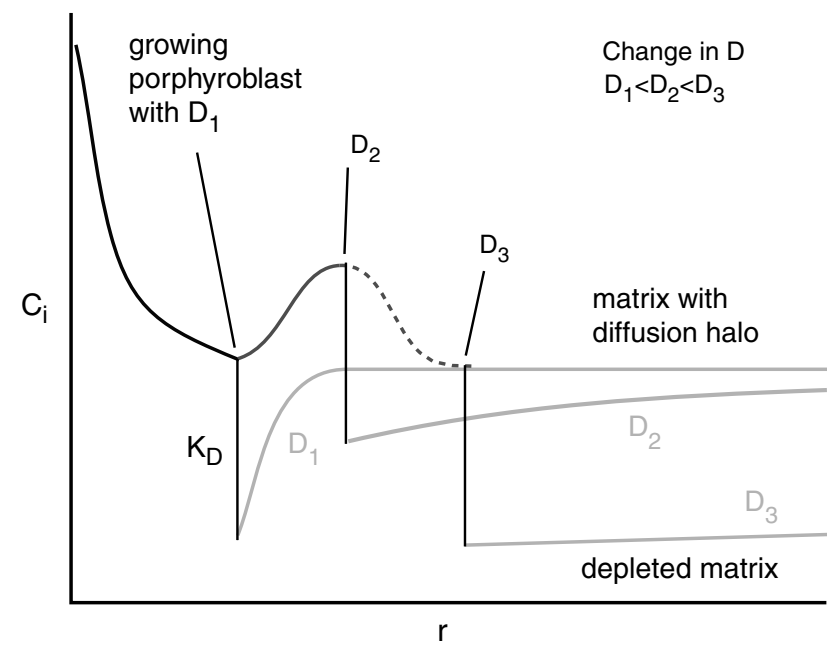

Fig. 6 Illustration of the development of second maximums due to thermally accelerated diffusion. Small, steep diffusion halos will develop initially. The halos widen as diffusion accelerates with increasing temperatures resulting in relaxation of the diffusion halo. Finally the matrix is depleted globally and further garnet growth will lead to decreasing concentrations were found in the samples. Epidote and apatite seem to have been stable up to peak metamorphic conditions.

Square root of time growth rate law

We additionally investigated the REE profiles produced if we assume an overall (non-accelerated) diffusion-limited growth rate as defined by a square root of time growth rate law. The most striking difference in the resulting profiles is the extremely rapid decrease of the central peaks to within approximately $0.8 \mu \mathrm{m}$, which reflects the very rapid initial garnet growth rate when a square root of time growth rate law is used (Fig. 7). In addition, the second peaks appear later in the growth history (further towards the rim) and their amplitude is lower. The very sharp central peaks predicted by this growth rate law suggest that the peaks are very likely missed because of small uncertainties in the central cut location. In addition, such small peaks would require a very small spot size analysis of $<1 \mu \mathrm{m}$. Only small amounts of volume diffusion would be needed to level out such a sharp central peak. Given the observed trace-element patterns, we therefore consider it unlikely that garnet growth occurred by a square root of time growth rate law over the whole growth period. These issues highlight the potential of REEs to trace growth rates, which in turn may help to distinguish between different growth mechanisms.

\section{Effect of modeling parameters}

The position and height of the second maximum was found to be strongly dependent on the activation energy $(Q)$ of the diffusion equation, which is a measure of how fast the diffusivity changes with temperature. Higher values for $Q$ shift the second maxima towards the center, implying occurrence earlier in the garnet growth history (Fig. 8a).

Figure $8 \mathrm{~b}$ shows the effect of different pre-exponential diffusion factors and its influence on the secondary peak position and its height. With decreasing pre-exponential diffusion factors, the core peak becomes less pronounced and the secondary peak is shifted further towards the rim. This effect reflects the steep diffusion halo that develops at low diffusion rates, along with late diffusion halo relaxation. Where the pre-exponential diffusion factors are large, negligible diffusion halos are produced, and the core-rim zonations approach those predicted by Rayleigh fractionation. The Rayleigh model is therefore viewed as an end member case in our model, where REE transport to the crystal is not diffusion limited. 


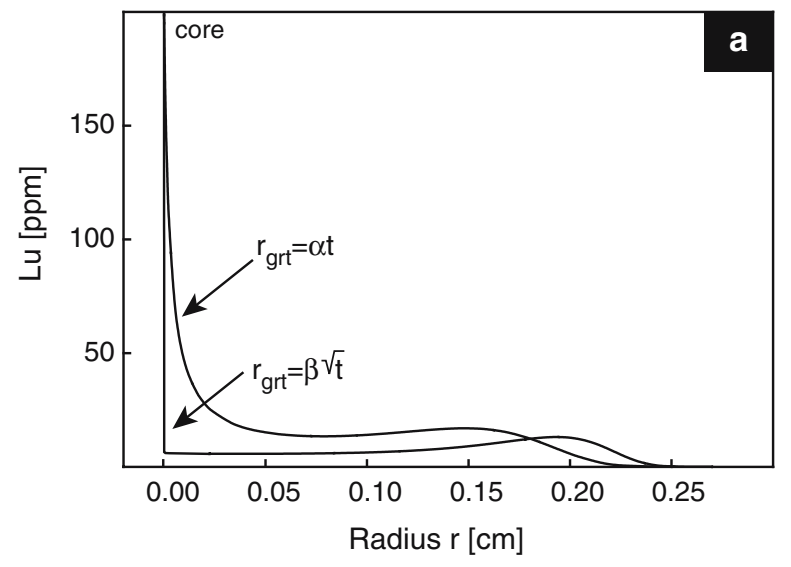

Fig. 7 Different growth rate laws result in very differently shaped trace element zoning profiles. A linear radial growth rate law is in agreement with surface kinetics controlled garnet growth, while diffusion controlled growth can result in a square

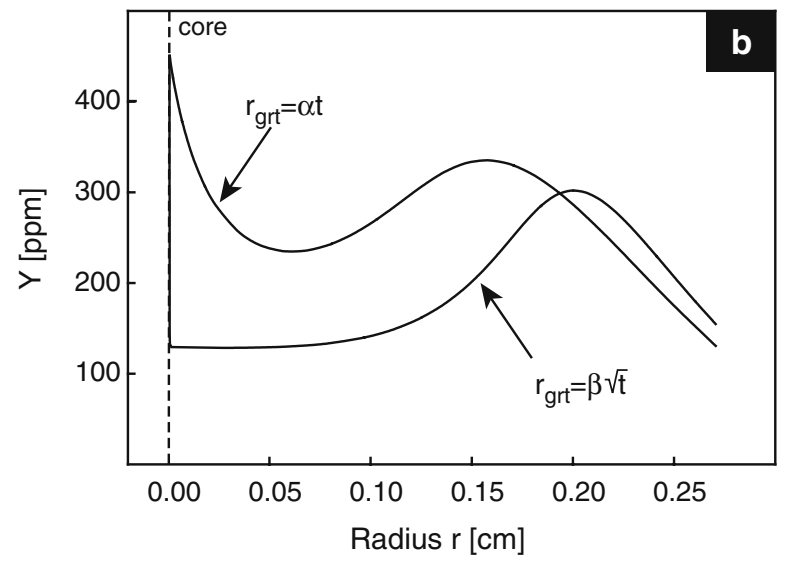

root of time growth rate law. The model parameters for Fig. 7a and Fig. $7 \mathrm{~b}$ are the same as for Fig. 5a ( Lu) and b (Y), respectively $\left(t=12\right.$ m.y.; $\alpha=2.25 \times 10^{-8} \mathrm{~cm} /$ year; $\beta=7.79 \times 10^{-5} \mathrm{~cm} /$ year $)$
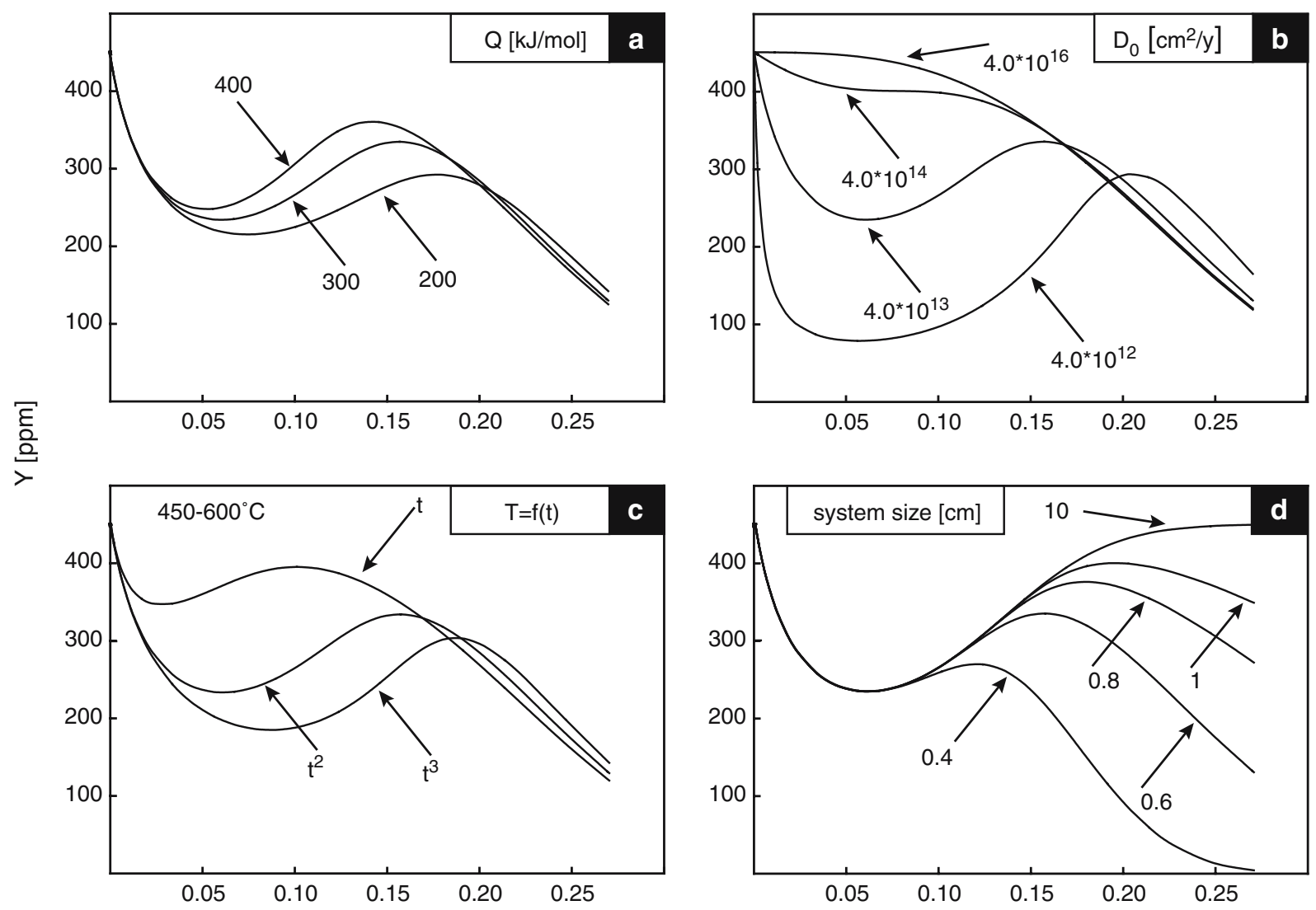

Radius [cm]

Fig. 8 Modeled yttrium concentrations versus garnet radius illustrate the effects of different input parameters. Note that the position and height of the second maxima is very sensitive to changes in all parameters as illustrated in: a for activation energy, $Q ; \mathbf{b}$ for pre-exponential diffusion factor, $D_{0}$; $\mathbf{c}$ for temperature evolution as a function of time; $\mathbf{d}$ for system size. Additional input parameters are: $K_{\mathrm{D}}=15 ; Q=300 \mathrm{~kJ} / \mathrm{mol}$ (except $8 \mathrm{a}) ; D_{0}=4.0 \times 10^{13} \mathrm{~cm}^{2} /$ year $($ except $8 \mathrm{~b})$; temperature increases from 450 to $600^{\circ} \mathrm{C}$ with $\mathrm{T} \sim \mathrm{t}^{2}$ (except $8 \mathrm{c}$ ); system size $=0.60 \mathrm{~cm}($ except $8 \mathrm{~d})$ 
The model is very sensitive to the temperature evolution and modeled size of the system. A linear temperature increase from 450 to $600^{\circ} \mathrm{C}$ would result in a much earlier, and higher, second maxima, reflecting relaxation of the diffusion halo early in the growth history. An increase in temperature proportional to $\mathrm{t}^{3}$ would result in a lower second maximum further towards the rim (Fig. 8c).

The height of the second maximum increases towards the rim of the garnet as the system size increases (Fig. 8d). The second maximum has a low peak height and is shifted core wards when the system size is small, approaching the "Rayleigh limit". At infinite reservoir size (corresponding to a very small modal abundance of garnet), the height of the second maxima reaches the initial starting value, reflecting complete diffusion relaxation and unlimited element availability. It is important to note in this context that the Rayleigh-like depletion that occurs on the rim ward side of the second maximum does not imply that the depletion halo is fully relaxed at this stage of garnet growth.

Systematic shift of peaks

The second maximum in the REE pattern is the product of thermally activated diffusion due to temperature increase during prograde garnet growth. The absolute height and the position of this peak is dependant on the temperature evolution, the system size, the activation energy, and the pre-exponential diffusion factor. The magnitude of the diffusion coefficient and its temperature dependence determine the size and position of the secondary maximum for a given growth history for garnet (Fig. 8). For example, the diffusion coefficient for $\mathrm{Y}$ is lower than that of $\mathrm{Lu}$ at $450^{\circ} \mathrm{C}$. Hence, the second maximum in $\mathrm{Y}$ appears further towards the $\operatorname{rim}$ for $\mathrm{Y}$ as compared to $\mathrm{Lu}$, reflecting a later diffusion halo relaxation for $\mathrm{Y}$ compared to $\mathrm{Lu}$.

The diffusion coefficients will be primarily constrained by differences in radii, assuming all REEs have the same charge. Volume diffusion studies of REEs in melts and minerals such as feldspar, calcite, apatite, fluorite, and garnet indicate similar diffusion behavior or a weak systematic decrease of diffusion coefficients with increasing ionic radius (Cherniak 1998a, b, 2000, 2003; Cherniak et al. 2001; Van Orman et al. 2002; Tirone et al. 2005; Koepke and Behrens 2001). In addition, diffusion studies in zircons and diopsides found a strong relation between diffusion rates and changes in ionic radii (Cherniak et al. 1997; Van Orman et al. 2001). Such a strong effect on the effective bulk diffusion coefficient as a function of radii appears to be required to explain the observed shifts of the second maximum.

\section{Incorporation of the light REE}

Although the HREEs are well explained by the abovedescribed model, it is somewhat more difficult to explain the behavior of the light REEs, which have no apparent central peak but a peak near the rim. Nevertheless, the successive shift of the peak towards the rim suggests that Sm uptake might also be diffusion limited. Indeed, it is possible that a very narrow $\mathrm{Sm}$ central peak, expected to be much narrower than that for the HREEs, was simply missed during sample sectioning. In addition, for very narrow central peaks, even small amounts of volume diffusion would tend to erase them. A small $\mathrm{Sm}$ matrix diffusion coefficient would be consistent with the generally observed decrease in the diffusion coefficient with increasing ionic radii, which, in turn, is consistent with an assumed narrow central peak (see Fig. 8b).

Estimation of the partition coefficient using the central peak concentrations and the whole rock composition is not possible for the LREE due to the lack of a central peak. Furthermore, LREE are distributed between several minerals including some potentially refractory minerals like epidote (e.g., Tribuzio et al. 1996; Sassi et al. 2000; Hermann 2002; Spandler et al. 2003; Sorensen 2005). The latter immobilize a certain amount of the total LREE during the time of garnet growth, which reduces the LREE concentrations in the participating matrix. The whole-rock concentration for the participating matrix therefore needs to be corrected for epidote content. The trace-element distributions given in Hermann (2002) were used to estimate the Sm concentration of the participating matrix minerals. This calculation leads to a significant reduction of the original whole rock concentration. A $K_{D}^{\text {grt/whole rock }}$ of 10 for Sm was finally fitted along with the diffusion input parameters to match the additional peak occurring towards the rim, although any smaller $K_{D}$ (but larger than 1) accompanied by an increased whole-rock concentration results in similar zoning. Our fitted $K_{D}$ is higher than the published $K_{D}^{\text {grt/cpx }}$ values of natural eclogites for Sm (Messiga et al. 1995; Bocchio et al. 2000), which lies in the range of 0.8-2.9. The values fit estimates from Sassi et al. (2000) ranging from 1.7 to 16.9 (median: 7.25) for the Central Dabie Shaw eclogites. The calculated zoning profile (Fig. 9) reproduces the measured data except for the predicted, very narrow central peak, which was likely missed due to small errors in making the central cuts. In addition, the 


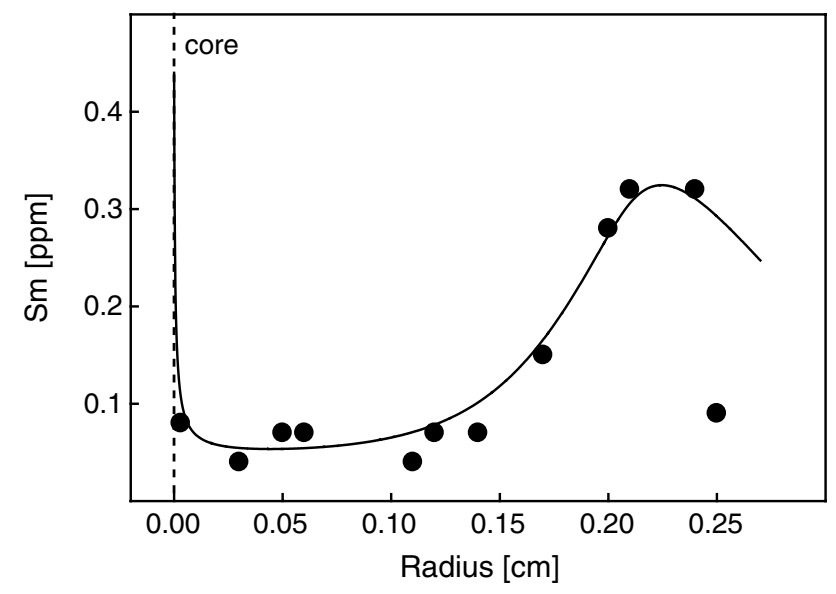

Fig. 9 Fit of measured Sm data versus radius using the transient, polythermal matrix diffusion model. The resulting zoning profile follows the measured data except that a very narrow central peak is predicted and the rapid decrease of Sm data at the outermost border is not modeled. Nevertheless, Sm uptake is likely also diffusion-controlled. Because the central peak is predicted to be so narrow, it can easily be missed or eliminated by even low amounts of volume diffusion. Input parameters are: $K_{\mathrm{D}}=10$; system size $=0.60 \mathrm{~cm} ; \quad Q=380 \mathrm{~kJ} / \mathrm{mol} ; \quad D_{0}=2.7 \times 10^{17} \mathrm{~cm}^{2} /$ year; temperature increases from 450 to $600^{\circ} \mathrm{C}$ with $\mathrm{T} \sim \mathrm{t}^{2}$

model does not predict the measured Sm profile at the outermost border. Nevertheless, we conclude that the LREE uptake is likewise diffusion-controlled, similar to the HREE uptake described above, because the overall REE patterns are a function of $Z$ for the HREES.

Implications for $\mathrm{Lu}-\mathrm{Hf}$ and $\mathrm{Sm}-\mathrm{Nd}$ geochronology

Lapen et al. (2003) used the differences in zoning patterns in $\mathrm{Lu} / \mathrm{Hf}$ and $\mathrm{Sm} / \mathrm{Nd}$ ratios that are predicted by Rayleigh fractionation to explain differences in ${ }^{176} \mathrm{Lu}-{ }^{176} \mathrm{Hf}$ and ${ }^{147} \mathrm{Sm}-{ }^{143} \mathrm{Nd}$ ages obtained from the same sample from the ZSFO. They concluded that the high $\mathrm{Lu} / \mathrm{Hf}$ ratios in garnet cores, relative to more uniform core-to-rim variations in $\mathrm{Sm} / \mathrm{Nd}$ ratios, produced ${ }^{176} \mathrm{Lu}-{ }^{176} \mathrm{Hf}$ ages that are weighted towards the beginning of the garnet growth history, provided peak metamorphic temperatures did not significantly exceed the isotopic blocking temperatures. In addition, the difference between the ${ }^{176} \mathrm{Lu}-{ }^{176} \mathrm{Hf}$ and ${ }^{147} \mathrm{Sm}-{ }^{143} \mathrm{Nd}$ ages should be a function of garnet growth rates, where, for example, rapid-slow-rapid garnet growth provides the largest spread between the two ages, and hence the best approximation of the duration of prograde garnet growth (Lapen et al. 2003).

The garnet size distribution will also affect ${ }^{176} \mathrm{Lu}-{ }^{176} \mathrm{Hf}$ and ${ }^{147} \mathrm{Sm}-{ }^{143} \mathrm{Nd}$ ages recorded in garnet. Major element zonations, for example, can be used as time markers if diffusion is fast enough to prevent development of diffusion halos, assuming that all porphyroblasts precipitated the same chemical compositions at any point in time. Because our major element profiles approximately plot on top of each other if their rims are aligned, we can conclude that small garnets will only record the youngest part of the growth history of a garnet population of different sizes. Different garnet sizes in such rocks will therefore record different parts of the prograde growth path. A bulk garnet separate would be expected to produce little spread between ${ }^{176} \mathrm{Lu}-{ }^{176} \mathrm{Hf}$ and ${ }^{147} \mathrm{Sm}-{ }^{143} \mathrm{Nd}$ ages. In terms of core-rim zonation in HREEs, including $\mathrm{Lu}$ and $\mathrm{Y}$, there is also the possibility that a ${ }^{176} \mathrm{Lu}-{ }^{176} \mathrm{Hf}$ age might be weighted towards the end of the garnet growth history in the case of very low diffusion rates (Fig. 8b) or an overall diffusion-limited garnet growth mechanism (Fig. 7). Although the highest concentrations are reached in the cores in both cases, the integrated $\mathrm{Lu}$ contents are weighted toward the rim due to the significant peak close to the rim.

A Lu/Hf age based on bulk garnet separates can therefore result in any age between the onset and the ending of the garnet growth history. The degree to which $\mathrm{Lu} / \mathrm{Hf}$ ages are skewed towards the onset or the ending of garnet growth depends on the Lu zoning pattern, the growth rates, and the crystal-size distribution. These parameters are the key for interpreting age data in terms of the metamorphic history, and same conclusions apply to the $\mathrm{Sm} / \mathrm{Nd}$ ages.

Diffusion-limited uptake of the REEs during garnet growth not only affects the volume-weighted $\mathrm{Lu}$ and Sm abundances and their relations to geochronology over the garnet growth interval, but also exerts an important control on overall $\mathrm{Lu} / \mathrm{Hf}$ and $\mathrm{Sm} / \mathrm{Nd}$ ratios of garnet, which in turn directly affects the precision of isochrons. ${ }^{176} \mathrm{Lu} /{ }^{177} \mathrm{Hf}$ and ${ }^{147} \mathrm{Sm} /{ }^{144} \mathrm{Nd}$ ratios reported for garnets vary greatly in the literature, and ratios that are lower than those expected based on $K_{D}$ 's are commonly ascribed to the effects of inclusions (e.g., Scherer et al. 2000), which has motivated development of chemical methods that might preferentially remove such inclusions (Amato et al. 1999). An alternative is that diffusion-limited $\mathrm{Lu}$ and $\mathrm{Sm}$ uptake may be responsible for producing the relatively low ${ }^{176} \mathrm{Lu} /{ }^{177} \mathrm{Hf}$ and ${ }^{147} \mathrm{Sm} /{ }^{144} \mathrm{Nd}$ ratios measured for some garnets in geochronological studies.

We calculated the isotopic ratios for an isothermal case, where a $1 \mathrm{~mm}$ sized garnet is grown in $10 \mathrm{~m} . \mathrm{y}$. using a constant radial growth rate law. The initial $\mathrm{Lu}$ and $\mathrm{Hf}$ contents of the modeled system are $0.5 \mathrm{ppm} \mathrm{Lu}$ and 5 ppm Hf, which closely reflects our ZSFO sample. Concentration profiles for $\mathrm{Lu}$ were calculated with varying diffusion coefficients, from $1.0 \times 10^{-10}$ to 
$1.0 \times 10^{-4} \mathrm{~cm}^{2} /$ year, the latter of which approximates a Rayleigh process for the chosen growth rate. A system Peclet number can be calculated as the product of the growth rate and the characteristic diffusion distance, divided by the diffusion coefficient. The latter was estimated using $\sqrt{ } 4 \times \mathrm{D}_{\mathrm{REE}} \times t$. The $K_{D}^{\text {grt/whole rock }}$ for $\mathrm{Lu}$ is taken to be 400 , close to our best-fit $K_{D}$. High peclet numbers are hence indicative of slow diffusion rates as compared to growth rates. Measured Hf concentrations in our garnets were below the detection limit of the LA-ICP-MS measurements (approximately $0.5 \mathrm{ppm}$ ). Zirconium contents were relatively constant from core to rim when high- $\mathrm{Zr}$ spots are ignored. These high-Zr spots are also high in Hf and are interpreted to reflect the presence of small zircon inclusions. We assume that $\mathrm{Hf}$ contents are relatively homogeneous from core to rim in the garnets. Maintaining Hf concentrations in our modeled garnets to be constant at $0.5 \mathrm{ppm}$ requires $\mathrm{Hf}$ diffusion to be greater than $1.0 \times 10^{-8} \mathrm{~cm}^{2} /$ year and a $K_{D}^{\text {grt } / \text { whole rock }}$ of 0.1 . Slower diffusion rates would increase the Hf concentration towards the rim and hence should qualitatively result into even lower ${ }^{176} \mathrm{Lu} /{ }^{177} \mathrm{Hf}$ ratios when compared to our calculated ratios.

The relations between ${ }^{176} \mathrm{Lu} /{ }^{177} \mathrm{Hf}$ ratios and Peclet numbers for different system sizes indicate that ${ }^{176} \mathrm{Lu} /{ }^{177} \mathrm{Hf}$ ratios will be always very low in systems that have high Peclet numbers (slow diffusion relative to growth rate), reflecting a narrow central peak and hence low overall concentration for Lu (Fig. 10a). If the growth rate is slow compared to diffusion (small Peclet numbers), the ${ }^{176} \mathrm{Lu} /{ }^{177} \mathrm{Hf}$ ratios increase dramatically as a function of system size. This effect can be envisioned to reflect competition for elements, limiting the overall availability of $\mathrm{Lu}$ in small system sizes. In contrast, for large (but not infinite) system sizes and fast diffusion, the core-rim $\mathrm{Lu}$ profile produces high ${ }^{176} \mathrm{Lu} /{ }^{177} \mathrm{Hf}$ ratios, essentially matching that predicted for Rayleigh fractionation (Peclet number approach zero). Rim isotopic compositions are always lower where diffusion is slow and the matrix is depleted. Rim ${ }^{176} \mathrm{Lu} /{ }^{177} \mathrm{Hf}$ ratios, however, tend towards zero in small system sizes when the entire reservoir is exhausted early in the growth history. In such systems, the rim isotopic compositions can seriously hamper $\mathrm{Lu} / \mathrm{Hf}$ geochronology.

Concentration profiles for $\mathrm{Sm}$ were calculated using varying diffusion coefficients from $1.0 \times 10^{-12} \mathrm{~cm}^{2} /$ year to $1.0 \times 10^{-6} \mathrm{~cm}^{2} /$ year. The $K_{D}^{\text {grt } / \text { whole rock }}$ was set to 10 along with an initial Sm concentration of $0.05 \mathrm{ppm}$, which closely reflects our system (see above). Unfortunately, despite the greater sensitivity of the ion probe measurements relative to LA-ICP-MS, Nd contents remained very low and had large errors, making it difficult to evaluate core-rim zoning. Assuming a nonaccelerated system, $\mathrm{K}_{\mathrm{D}}<1$, and very low diffusion rates, the resulting $\mathrm{Nd}$ concentration profile will be essentially flat, despite a narrow central depletion. Hence we have taken a constant $0.05-\mathrm{ppm} \mathrm{Nd}$ concentration profile as an input parameter based on our highest measured $\mathrm{Nd}$ concentrations. Although it is more difficult to constrain our model for the ${ }^{147} \mathrm{Sm}-{ }^{143} \mathrm{Nd}$ isotope system due to the lower levels of $\mathrm{Sm}$ and $\mathrm{Nd}$ in garnet, the interplay between Peclet number and ${ }^{147} \mathrm{Sm} /{ }^{144} \mathrm{Nd}$ ratios is quite similar to that calculated for ${ }^{176} \mathrm{Lu} /{ }^{177} \mathrm{Hf}$ ratios (Fig. 10b) except that the maximum isotopic ratio that can be obtained is much smaller and the rim isotopic compositions have a much less pronounced effect. Moreover, the effect of the size of the system is less pronounced. Although it is clear that LREE-enriched inclusions in garnet can affect ${ }^{147} \mathrm{Sm} /{ }^{144} \mathrm{Nd}$ ratios, our results offer an alternative explanation for low ${ }^{147} \mathrm{Sm} /{ }^{144} \mathrm{Nd}$ ratios in garnet, which may reflect diffusion-limited REE uptake.

\section{Conclusions}

Core-rim zonations in REEs in garnet reflect the interplay of growth and diffusion rates, which may produce profiles that are substantially different than those produced by Rayleigh fractionation. Garnets in the Zermatt-Saas Fee eclogite of the Western Alps grew during prograde metamorphism from $\sim 450$ to $600^{\circ} \mathrm{C}$, and changes in diffusion rates relative to growth rates and the size of matrix diffusion domains produced core-rim zonations for the HREEs that have narrow core peaks and broad secondary shoulders toward the rim; neither of these features can be explained by a Rayleigh process. Under diffusionlimited conditions, the position of the secondary shoulder migrates rim ward from $\mathrm{Lu}$ to $\mathrm{Sm}$ assuming systematically lower apparent bulk diffusion rates with increasing ionic radii. Secondary shoulders have been observed in other garnet-bearing rocks, and these have been ascribed to open-system behavior or mineral breakdown reactions, but we argue that they may also reflect growth under diffusion-limited conditions.

Variations in the topology of $\mathrm{Lu}$ and $\mathrm{Sm}$ profiles in garnet under diffusion-limited growth relative to Rayleigh fractionation will produce distinctly different time-volume weighted ${ }^{176} \mathrm{Lu}$ and ${ }^{147} \mathrm{Sm}$ abundances, which in turn will produce different ${ }^{176} \mathrm{Lu}-{ }^{176} \mathrm{Hf}$ and ${ }^{147} \mathrm{Sm}-{ }^{143} \mathrm{Nd}$ ages for bulk garnet separates. Moreover, diffusion-limited growth will produce lower ${ }^{176} \mathrm{Lu} /{ }^{177} \mathrm{Hf}$ 


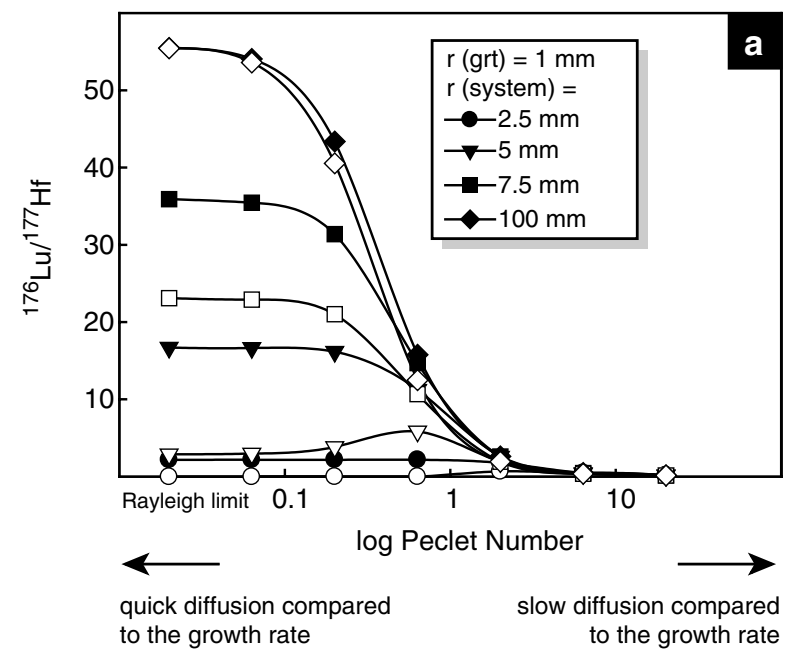

Fig. 10 Plot of modeled ${ }^{176} \mathrm{Lu} /{ }^{177} \mathrm{Hf}$ (a) and ${ }^{147} \mathrm{Sm} /{ }^{144} \mathrm{Nd}$ (b) ratios against $\log$ Peclet numbers for different system sizes (modeled garnet is $1 \mathrm{~mm}$, grown in $10 \mathrm{~m} . \mathrm{y}$.). Filled symbols give the isotopic ratio for a single whole garnet; open symbols give the ratios of the outermost $0.05 \mathrm{~mm}$ of the respective garnet. The figure illustrates that ${ }^{176} \mathrm{Lu} /{ }^{177} \mathrm{Hf}$ ratios will be very low in systems that have high Peclet numbers (slow diffusion relative to growth rate), reflecting a narrow central peak but low overall concentration. If the growth rate is slow compared to diffusion

and ${ }^{147} \mathrm{Sm} /{ }^{144} \mathrm{Nd}$ ratios for bulk garnet, decreasing the precision of $\mathrm{Lu}-\mathrm{Hf}$ and $\mathrm{Sm}-\mathrm{Nd}$ isochrons. Although poor-precision isochrons have been commonly ascribed to inclusions, diffusion-limited growth is an alternative explanation, and these may be distinguished through detailed core-rim analyses of REE patterns. It is important to note that accurate location of central cut sections is critical in these studies, which can only be accomplished using X-ray tomography.

Our results provide insight into application of $\mathrm{Lu}-\mathrm{Hf}$ and $\mathrm{Sm}-\mathrm{Nd}$ garnet geochronology. In the relatively cool eclogite terrane of our study, samples that are relatively hydrous, which may increase matrix diffusion rates, and those that have relatively widely dispersed, small garnets (large system sizes and fast diffusion compared to growth rates) should most closely match the REE profiles produced by Rayleigh fractionation, which should produce ${ }^{176} \mathrm{Lu}-{ }^{176} \mathrm{Hf}$ and ${ }^{147} \mathrm{Sm}-{ }^{143} \mathrm{Nd}$ ages that are weighted toward the beginning and end of garnet growth, respectively, as proposed by Lapen et al. (2003). In addition, ${ }^{176} \mathrm{Lu} /{ }^{177} \mathrm{Hf}$ and ${ }^{147} \mathrm{Sm} /{ }^{144} \mathrm{Nd}$ ratios will be relatively high in such samples, increasing isochron precision. In contrast, dry samples, or samples that contain large, closely spaced garnets are expected to produce the poorest isochrons because such garnets are expected to have narrow central peaks due to slow diffusion rates compared to their growth rate, along with low overall

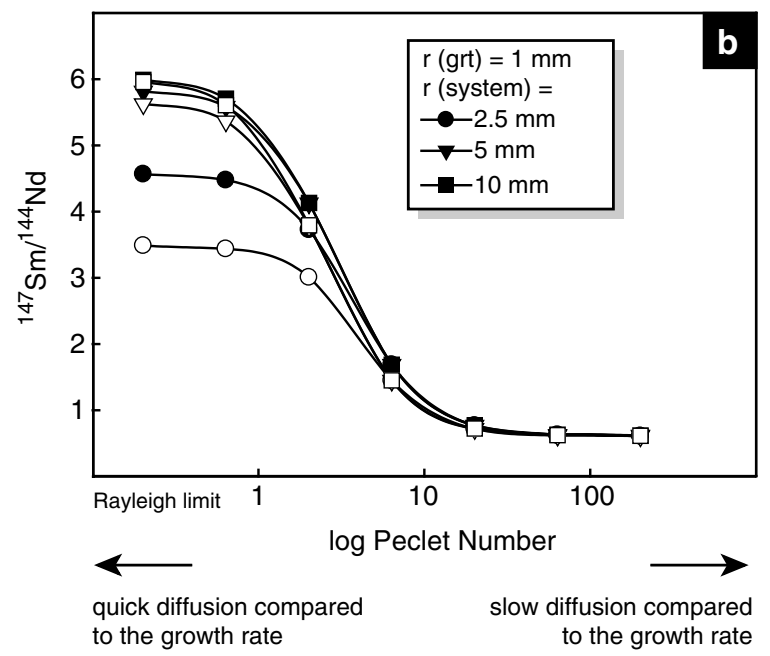

(small Peclet numbers), the ${ }^{176} \mathrm{Lu} /{ }^{177} \mathrm{Hf}$ ratio is a function of system size only due to the overall availability of Lu. Rim isotopic compositions are always lower where diffusion is slow or the matrix is depleted. The dependence of ${ }^{147} \mathrm{Sm} /{ }^{144} \mathrm{Nd}$ ratios on the Peclet number is quite similar to that calculated for ${ }^{176} \mathrm{Lu} /{ }^{177} \mathrm{Hf}$ ratios except that the maximum isotopic ratio that can be obtained is much smaller and the rim isotopic compositions have a much less pronounced effect

element availability. Higher temperature eclogite terranes may produce high-precision ${ }^{176} \mathrm{Lu}-{ }^{176} \mathrm{Hf}$ and ${ }^{147} \mathrm{Sm}-{ }^{143} \mathrm{Nd}$ ages because garnet will be less likely to have grown under diffusion-limited conditions, although the prograde garnet growth record will be lost if temperatures significantly exceeded the $\mathrm{Lu}-\mathrm{Hf}$ and $\mathrm{Sm}-\mathrm{Nd}$ blocking temperatures. In silicic (pelitic) lithologies, higher water contents may enhance matrix diffusion rates, producing core-to-rim REE zonations that match those expected for Rayleigh fractionation, resulting in high-precision isochrons that may also provide information on the duration of prograde garnet growth through contrasting ${ }^{176} \mathrm{Lu}-{ }^{176} \mathrm{Hf}$ and ${ }^{147} \mathrm{Sm}-{ }^{143} \mathrm{Nd}$ ages, assuming that blocking temperatures were not exceeded.

Acknowledgments This study was funded by Swiss National Science Foundation grant SNF2100-066996 to LPB and U.S. National Science Foundation grant EAR-0309853 to CMJ. Many thanks to A.W. Hofmann for granting time access to the ionprobe, as well as T. Lapen for fruitful discussions. The constructive reviews of J. Van Orman and R. Dohmen and the editorial handling of J. Hoefs significantly improved the manuscript and were greatly appreciated.

\section{Appendix}

Fick's second law in spherical coordinates is used to describe the concentration distribution in time and 
space in the matrix surrounding a growing garnet porphyroblast (e.g., Lasaga 1998):

$\frac{\partial c}{\partial t}=D \frac{\partial^{2} c}{\partial r^{2}}+\frac{2 D}{r} \frac{\partial c}{\partial r}$,

where $C$ is the average concentration of a trace element in the matrix, $r$ is the radius and $t$ is the time. Diffusion in the growing garnet was ignored. It is assumed to be many orders of magnitude smaller than that in the matrix. This choice is justified by the fact that extremely sharp peaks in concentration are preserved in garnet for at least the heavy REE (Fig. 3), indicating that the integrated effect of diffusion was very small during the $\mathrm{P}-\mathrm{T}-\mathrm{t}$ loop experienced by the rocks in the Zermatt-Saas Fee ophiolite. The diffusion coefficient $D$ of the REE in the matrix is calculated as a function of temperature following the Arrhenius equation:

$D=D_{0} e^{-\frac{Q}{R T}}$

where $D_{0}$ is the pre-exponential diffusion factor, $Q$ is the activation energy, $T$ is the temperature and $R$ is the universal gas constant. An effective diffusion coefficient is used here. It describes the bulk response of the matrix to a sink or source term for a specific REE. It is a macroscopic property specific to a given sample which includes the effects of porosity and structure of the grain boundary, and the potential contribution of intra-grain diffusion, as well as potential contribution of the accumulation of REE on grain boundaries (see e.g., Brady 1983; Baumgartner and Rumble 1988; Herzig and Mishin 1998; Dohmen and Chakraborty 2003; Hiraga et al. 2004).

The domain solved for is the matrix between the garnet surface and the limits of the spherical system $\left(r_{\text {sys }}\right)$, which is taken to be the half the distance between the center of the garnet modeled and its nearest neighbor. The diffusion equation was solved numerically by applying a Crank-Nicholson scheme (e.g., Crank 1975). A standard no flow boundary condition was applied to the outer boundary at $r_{\text {sys. }}$. This implies that each garnet has a maximum volume from which material can be transported to the growing crystal corresponding to the system size. Using a no flow boundary allows us to simulate approximately a Rayleigh fractionation.

The left hand boundary of the system moved at the speed of the radius of the garnet, $r_{\mathrm{grt}}$. Growth of garnet is initiated in the center of the modeled sphere at the beginning and its radius increases with time following either a linear: $r_{\mathrm{grt}}=\alpha t$

or a square root law

$r_{\mathrm{grt}}=\beta \sqrt{t}$

The constants $\alpha$ and $\beta$ were adjusted to yield the desired garnet size after the overall growth period. The concentration value at $r_{\text {grt }}$ is determined by the requirement of equilibrium

$K_{D}=\frac{c_{\mathrm{grt}}^{r_{\mathrm{grt}}}}{c^{r_{\mathrm{grt}}}}$

and the balance of mass between the flux of REE entering the garnet, $\Delta_{\text {grt }}$, and the fluxes of the REE leaving or entering the system due to movement of the boundary, $J_{\mathrm{b}}$, and the diffusive flux, $J_{\mathrm{D}}$ due to the near field gradient in the diffusion potential at the moving boundary:

$J_{\mathrm{grt}}+J_{b}+J_{D}=0$

Solution of the right hand boundary condition was achieved by first assigning an upper and lower estimate to the concentration in the matrix at $r_{\text {grt }}$, solving the set of Crank-Nicholson finite difference equations and to calculate the flux balance. The root to equation (6) was subsequently found by the interval halving technique (e.g., Press et al. 1992). A similar numerical approach was used by Eiler et al. (1994). The finite difference mesh points were remapped for each time step to account for the moving boundary.

Overall mass balance was calculated for each time step using numerical integration (Simpson rule, Press et al. 1992) of garnet and matrix compositions. The overall net mass gain or loss at the end of a simulation never exceeded $0.01 \%$ of the REE mass in the system, even if over $99 \%$ of the REEs were calculated to be in the garnet in some cases.

\section{References}

Amato JM, Johnson CM, Baumgartner LP, Beard BL (1999) Rapid exhumation of the Zermatt-Saas ophiolite deduced from high-precision $\mathrm{Sm}-\mathrm{Nd}$ and $\mathrm{Rb}-\mathrm{Sr}$ geochronology. Earth Planet Sci Lett 171:425-438

Barnicoat AC (1988) Zoned high-pressure assemblages in pillow lavas of the Zermatt-Saas ophiolite zone, Switzerland. Lithos 21:227-236

Barnicoat AC, Fry N (1986) High pressure metamorphism of the Zermatt-Saas ophiolite zone, Switzerland. J Geol Soc London 143:603-618 
Baumgartner LP, Rumble D III (1988) Transport of stable isotopes: I: development of a kinetic continuum theory for stable isotope transport. Contrib Mineral Petrol 98:417-430

Baumgartner LP, Skora S, Mahlen N, Johnson C (2005) Modeling diffusion limited uptake of trace elements by eclogite garnets. GSA AbstrProgr 37(7):52

Bearth P (1959) Über Eklogite, Glaucophanschiefer, und metamorphe Pillowlaven. Schweiz Mineral Petrogr Mitt 39:267286

Bearth P (1967) Die Ophiolithe der Zone von Zermatt-Saas Fee. Beitr Geol Karte Schweiz:p 132

Bearth P (1973) Gesteins und Mineralparagenesen aus den Ophiolithen von Zermatt. Schweiz Mineral Petrogr Mitt 53:299-334

Bocchio R, DeCapitani L, Ottolini L, Cella F (2000) Trace element distribution in eclogites and their clinopyroxene/garnet pair: a case study from Soazza (Switzerland). Eur J Mineral 12:147-161

Bowtell SA, Cliff RA, Barnicoat AC (1994) Sm-Nd isotopic evidence on the age of eclogitization in the Zermatt-Saas ophiolite. J Metam Geol 12:187-196

Brady JB (1983) Intergranular diffusion in metamorphic rocks. Am J Sci 283:181-200

Brown EH (1986) Geology of the Shuksan Suite, North Cascades, Washington, USA. In: Brown EH, Evans BW (eds) Blueschists and eclogites. GSA Memoir164:143-154

Bucher K, Fazis Y, de Capitani C, Grapes R (2005) Blueschists, eclogites, and decompression assemblages of the ZermattSaas ophiolite: High pressure metamorphism of subducted Tethys lithosphere. Am Mineral 90:821-835

Carlson WD (1989) The significance of intergranular diffusion to the mechanism and kinetics of porphyroblast crystallization. Contrib Mineral Petrol 103:1-24

Carlson WD (1991) Competitive diffusion-controlled growth of porphyroblasts. Min Mag 55:317-330

Carlson WD, Denison C (1992) Mechanisms of porphyroblast crystallization; results from high-resolution computed X-ray tomography. Science 257:1236-1239

Carlson WD, Denison C, Ketcham RA (1995) Controls on the nucleation and growth of porphyroblasts; kinetics from natural textures and numerical models. Geol J 30:207-225

Carlson WD, Ketcham R (2006) Formation of porphyroblastic textures. Geophys Res Abstr 8:09454

Cartwright I, Barnicoat AC (2002) Petrology, geochronology, and tectonics of shear zones in the Zermatt-Saas and Combin zones of the Western Alps. J Metam Geol 20:263281

Cashman KV, Ferry JM (1988) Crystal size distribution (CSD) in rocks and the kinetics and dynamics of crystallization. III metamorphic crystallization. Contrib Mineral Petrol 99:401415

Cherniak DJ (1998a) REE diffusion in calcite. Earth Planet Sci Lett 160:273-287

Cherniak DJ (1998b) Rare earth element and gallium diffusion in yttrium aluminum garnet. Phys Chem Mineral 26:156-163

Cherniak DJ (2000) Rare earth element diffusion in apatite. Geochim Cosmochim Acta 64:3871-3885

Cherniak DJ (2003) REE diffusion in feldspar. Chem Geol 193:25-41

Cherniak DJ, Hanchar JM, Watson EB (1997) Rare-earth diffusion in zircons. Chem Geol 134:289-301

Cherniak DJ, Zhang XY, Wayne NK, Watson EB (2001) Sr, Y, and REE diffusion in fluorite. Chem Geol 181:99-111

Chinner GA, Dixon JE (1973) Some high-pressure paragenesis of the Allalin Gabbro, Valais, Switzerland. J Petrol 14:185202
Crank J (1975) The mathematics of diffusion. Oxford University Press, p 414

Dal Piaz GV, Cortiana G, Del Moro A, Martin S, Pennacchioni G, Tartarotti P (2001) Tertiary age and paleostructural inferences of the eclogitic imprint in the Austroalpine outliers and Zermatt-Saas ophiolite, western Alps. Int J Earth Sci 90:668-684

Daniel CG, Spear FS (1998) Three-dimensional patterns of garnet nucleation and growth. Geology 26:503-506

Daniel CG, Spear FS (1999) The clustered nucleation and growth processes of garnet in regional metamorphic rocks from North-west Connecticut, USA. J Metam Geol 17:503-520

Denison C, Carlson WD (1997) Three-dimensional quantitative textural analysis of metamorphic rocks using high-resolution computed X-ray tomography; Part II, application to natural samples. J Metam Geol 15:45-57

Denison C, Carlson WD, Ketcham RA (1997) Three-dimensional quantitative textural analysis of metamorphic rocks using high-resolution computed X-ray tomography; part I, methods and techniques. J Metam Geol 15:29-44

Dewey JF, Helman ML, Turco E, Hutton DHW, Knott SD (1989) Kinematics in the western Mediterranean. In: Coward MP, Dietrich D, Park RG (eds) Alpine Tectonics. Geol Soc Spec Publ 45:265-283

Dohmen R, Chakraborty S (2003) Mechanism and kinetics of element and isotopic exchange mediated by a fluid phase. Am Mineral 88:1251-1270

Duchêne S, Blichert-Toft J, Luais B, Télouk P, Lardeaux JM, Albarède F (1997) The Lu-Hf dating of garnets and the ages of the Alpine high-pressure metamorphism. Nature 387:586-589

Eiler JM, Baumgartner LP, Valley JW (1994) Fast grain boundary: a Fortran-77 program for calculating the effects of retrograde inetrdiffusion of stable isotopes. Comp and Geosci 20:1415-1434

Escher A, Beaumont C (1997) Formation, burial and exhumation of basement nappes at crustal scale: a geometric model based on the Western Swiss-Italian Alps. J Struct Geol 19:955-974

Fischer GW (1978) Rate laws in metamorphism. Geochim Cosmochim Acta 42:1035-1050

Froitzheim N, Schmid SM, Frey M (1996) Mesozoic paleogeography and the timing of eclogite-facies metamorphism in the Alps: a working hypothesis. Eclogae Geol Helv 89:81-110

Ganguin J (1988) Contribution à la caractérisation du métamorphisme polyphase de la zone de Zermatt-Saas Fee (Alpes Valaisannes). Thèse (Diss) ETH Zürich, p 311

Günther D, Frischknecht R, Heinrich CA, Kahlert HJ (1997) Capabilities of an argon $193 \mathrm{~nm}$ excimer laser for laser ablation inductively coupled plasma mass spectrometry microanalysis of geological materials. J Anal Atom Spectro 12:939-944

Hellebrand E, Snow JE, Hoppe P, Hofmann AW (2002) Garnetfield melting and late-stage refertilization in "residual" abyssal peridotites from the central Indian ridge. J Petrol 43:2305-2338

Hermann J (2002) Allanite: thorium and light rare earth element carrier in subducted crust. Chem Geol 192:289-306

Herzig C, Mishin Y (1998) Grain boundary diffusion in metals. In: Kärger J, Heitjans P, Haberlandt R (eds) Diffusion in condensed matter. Vieweg, Wiesbaden, pp 90-115

Hickmott DD, Shimizu N, Spear FS, Selverstone J (1987) Trace element zoning in a metamorphic garnet. Geology 15:573-576

Hiraga T, Anderson IM, Kohlstedt DL (2004) Grain boundaries as reservoirs of incompatible elements in the Earth's mantle. Nature 427:699-703 
Hirsch DM, Ketcham RA, Carlson WD (2000) An evaluation of spatial correlation functions in textural analysis of metamorphic rocks. Geol Mat Res 2:1-42

Hollister LS (1966) Garnet Zoning: An interpretation based on the Rayleigh fractionation model. Science 154:1647-1650

Jochum KP, Dingwell DB, Rocholl A, Stoll B, Hofmann AW et al (2000) The preparation and preliminary characterization of eight geological MPI-DING reference glasses for insitu microanalysis. Geostand Newsl 24:87-133

Katzir Y, Avigad D, Matthews A, Garfunkel Z, Evans BW (2000) Origin, HP/LT metamorphism and cooling of ophiolitic mélanges in southern Evia (NW Cyclades), Greece. J Metam Geol 18:699-718

Kerrick DM, Lasaga AC, Raeburn SP (1991) Kinetics of heterogeneous reactions. In: Kerrick DM (ed) Contact metamorphism. Rev Mineral 26:585-666

Koepke B, Behrens H (2001) Trace element diffusion in andesitic melts: An application of synchrotron X-ray fluorescence analysis. Geochim Cosmochim Acta 65:1481-1498

Kretz R (1969) On the spatial distribution of crystals in rocks. Lithos 2:39-66

Kretz R (1973) Crystallization of garnet at two localities near Yellowknife. Can Mineral 12:1-20

Kretz R (1974) Some models for the rate of crystallization of garnet in metamorphic rocks. Lithos 7:123-131

Kretz R (1993) A garnet population in Yellowknife schist, Canada. J Metam Geol 11:101-120

Lanzirotti A (1995) Yttrium zoning in metamorphic garnets. Geochim Cosmochim Acta 59:4105-4110

Lapen TJ, Johnson CM, Baumgartner LP, Mahlen NJ, Beard BL, Amato JM (2003) Burial rates during prograde metamorphism of an ultra-high-pressure terrane: an example from Lago di Cignana, western Alps, Italy. Earth Planet Sci Lett 215:57-72

Lasaga AC (1986) Metamorphic reaction rate laws and development of reaction isograds. Min Mag 50:359-373

Lasaga AC (1998) Kinetic theory in the Earth sciences. Princeton University Press. Princeton, p 811

Longerich HP, Jackson SE, Günther D (1996) Laser ablation inductively coupled plasma mass spectrometric transient signal data acquisition and analyte concentration calculation. J Anal Atom Spectro 11:899-904

Mahlen NJ, Skora S, Johnson CM, Baumgartner LP, Lapen TJ, Beard BL, Pilet S (2005) Lu-Hf geochronology of eclogites from Pfulwe, Zermatt-Saas ophiolite, western Alps. Switzerland. Suppl Geochim Cosmochim Acta 69(10):A305

Mayer A, Abouchami W, Dal Piaz GV (1999) Eocene Sm-Nd age for the eclogitic metamorphism of the Zermatt-Saas ophiolite in Ayas Valley, Western Alps. Eur Union Geosci 10:A809

Messiga B, Tribuzio R, Bottazzi P, Ottolini L (1995) An ion microprobe study of trace element composition of clinopyroxenes from blueschists and eclogitized Fe-Ti-gabbros, Ligurian Alps, northwestern Italy: some petrologic considerations. Geochim Cosmochim Acta 59:59-75

Meth CE, Carlson WD (2005) Diffusion-controlled synkinematic growth of garnet from a heterogeneous precursor at Passo del Sole, Switzerland. Can Mineral 43:157-182

Meyer J (1983) Mineralogie und Petrographie des Allalingabbros. Dissertation Universität Basel, 329p

Oberhänsli R (1980) P-T-Bestimmungen anhand von Mineralanalysen in Eklogiten und Glaukophaniten der Ophiolite von Zermatt. Schweiz Mineral Petrogr Mitt 60:215-235

Oberhänsli R (1982) The P-T-history of some pillow lavas from Zermatt. Ofioliti 7:431-436
Oberhänsli R (1994) Subducted and obducted ophiolites of the Central Alps: paleotectonic implications deduced by their distribution and metamorphic imprint. Lithos 33:109-118

Patrick BE, Evans BW (1989) Metamorphic evolution of the Seward Peninsula blueschist terrane. J Petrol 30:531-555

Press WH, Teukolsky SA, Vetterling WT, Flannery BP (1992) Numerical Recipes in Fortran 77. Cambridge University Press: 933p

Reinecke T (1991) Ultrahigh- and high-pressure metamorphism and exhumation of oceanic sediments at Lago di Cignana, Zermatt-Saas zone, western Alps. Eur J Mineral 3:7-17

Reinecke T (1998) Prograde high- to ultrahigh-pressure metamorphism and exhumation of oceanic sediments at Lago di Cignana, Zermatt-Saas zone, western Alps. Lithos 42:147189

Roselle GT, Engi M (2002) Ultra high pressure (UHP) terrains: lessons from thermal modeling. Am J Sci 302:410-441

Rubatto D, Gebauer D, Fanning M (1998) Jurassic formation and Eocene subduction of the Zermatt-Saas Fee ophiolite: implications for the geodynamic evolution of the Central and Western Alps. Contrib Mineral Petrol 132:269-287

Sassi R, Harte B, Carswell DA, Yujing H (2000) Trace element distribution in Central Dabie eclogites. Contrib Mineral Petrol 139:298-315

Satori M (1987) Structure de la zone du Combin entre les Diablons et Zermatt. Eclogae Geol Helv 80:789-814

Scherer EE, Cameron KL, Blichert-Toft J (2000) Lu-Hf garnet geochronology: closure temperature relative to the $\mathrm{Sm}-\mathrm{Nd}$ system and the effects of trace minerals. Geochim Cosmochim Acta 64:3413-3432

Skora S, Mahlen N, Baumgartner LP, Johnson C, Pilet S (2005) Garnet zoning pattern, growth mechanisms and the development of Lu-depleted halos in eclogites. Suppl Geochim Cosmochim Acta 69(10):A403

Sorensen SS (2005) Accessory minerals, trace elements, fluids and subduction. Suppl Geochim Cosmochim Acta 69(10):A24

Spandler C, Hermann J, Arculus R, Mavrogenes J (2003) Redistribution of trace elements during prograde metamorphism from lawsonite blueschist to eclogite facies; implications for deep subduction-zone processes. Contrib Mineral Petrol 146:205-222

Spear FS, Daniel CG (1998) Three-dimensional imaging of garnet porphyroblast sizes and chemical zoning: nucleation and growth history in the garnet zone. Geol Mat Res 1:1-44

Spear FS, Daniel CG (2001) Diffusion control of garnet growth, Harpswell Neck, Maine USA. J Metam Geol 19:179-795

Spear FS, Kohn MJ, Florence P, Menard T (1991) A model for garnet and plagioclase growth in pelitic schists: implications for thermobarometry and $\mathrm{P}-\mathrm{T}$ path determinations. J Metam Geol 8:683-696

Spear FS, Selverstone J (1983) Quantitative P-T path from zoned minerals; theory and tectonic applications. Contrib Mineral Petrol 83:348-357

Stampfli GM, Marchant RH (1997) Geodynamic evolution of the Tethyan margins of the Western Alps. In: Pfiffner OA, Lehner P, Heitzman P, Müller S, Steck A (eds) Deep structures of the Swiss Alps, Results of NRP 20. Birkhäuser Verlag, Basel, pp 223-239

Stampfli GM, Mosar J, Marquer D, Marchant R, Baudin T, Borel $\mathrm{G}$ (1998) Subduction and obduction processes in the Swiss Alps. Tectonophysics 296:159-204

Tirone M, Ganguly J, Dohmen R, Langenhorst F, Hervig R, Becker H-W (2005) Rare earth diffusion kinetics in garnet: experimental studies and applications. Geochim Cosmochim Acta 69:2385-2398 
Tribuzio R, Messiga B, Vannucci R, Bottazzi P (1996) Rare earth element redistribution during high-pressure-low-temperature metamorphism in ophiolitic Fe-gabbros (Liguria, northwest Italy): Implications for light REE mobility in subduction zone. Geology 24:711-714

van der Klauw SNGC, Reinecke T, Stöckhert B (1997) Exhumation of ultrahigh-pressure metamorphic oceanic crust from Lago di Cignana, Piemontese zone, western Alps: the structural record in metabasites. Lithos 41:79-102

Van Orman JA, Grove TL, Shimizu N (2001) Rare earth element diffusion in diopside: influence of temperature, pressure, and ionic radius, and an elastic model for diffusion in silicates. Contrib Mineral Petrol 141:687-703

Van Orman JA, Grove TL, Shimizu N, Layne GD (2002) Rare earth element diffusion in a natural pyrope single crystal at 2.8 GPa. Contrib Mineral Petrol 142:416-424
Vance D, O’Nions RK (1990) Isotopic chronometry of zoned garnets: growth kinetics and metamorphic histories. Earth Planet Sci Lett 97:227-240

Weare JH, Stephens JR, Eugster HP (1976) Diffusion metasomatism and mineral reaction zones: general principles and application to feldspar alteration. Am J Sci 276:767-816

Whitehouse MJ, Platt JP (2003) Dating high-grade metamorphism-constraints from rare-earth elements in zircon and garnet. Contrib Mineral Petrol 145:61-74

Yang P, Rivers T (2002) The origin of Mn and Y annuli in garnet and the thermal dependence of $\mathrm{P}$ in garnet and $\mathrm{Y}$ in apatite in calc-pelite and pelite, Gagnon terrane, western Labrador. Geol Mat Res 4:1-35 